\title{
Monkeying around Anthropocene: Patterns of human-nonhuman primates' interactions in Brazil
}

\author{
Vitória Fernandes Nunes ${ }^{1 *}$; Priscila Macedo Lopes ${ }^{2}$ and Renata Gonçalves \\ Ferreira $^{3}$
}

\begin{abstract}
In Anthropocene, approximately $70 \%$ of all terrestrial ecosystems are highly modified by human activities and more than a half of all primate's species in the world are endangered. Here we present results of a systematic review on published articles with an Ethnoprimatology approach, aiming to assess the nationwide pattern and quality of proximity/interaction between human-nonhuman primates in Brazil, a country vulnerable to high deforestation rates while having the highest primate biodiversity in the world. The first article was published 29 years ago and add up to only 36 published articles until present time. Most studies were conducted in Atlantic forest, but higher number and diversity of interactions was described for Amazon. Sapajus, being a generalist and semi-terrestrial primate, was the most cited genus and had the greatest diversity of interactions, including garbage foraging and crop-raiding. Alouatta, the second most cite one, had more symbolic/mystic relationships. Some specialized or forest-specific primates are scarcely mentioned. Studies carried out in both rural and urban environment are almost equal in number but showed differences in types of interactions they describe: garbage foraging, crop-raiding by primates and food offering by humans happening in more urbanized areas and symbolic/mystic relationships and beliefs around nonhuman primates described in rural/indigenous settlements. We urge future studies to describe interactions and proximity carefully specifying the context where they occur. It is relevant to maintain the growing curve of Ethnoprimatological studies in Brazil as a way to aggregate information about different populations of species and help to base conservation strategies of co-existence.
\end{abstract}

Keywords: Ethnoprimatology; Human-Nonhuman Primate; Conservation.

\footnotetext{
1 Pós-Graduação em Meio Ambiente e Desenvolvimento - PRODEMA, Universidade Federal do Rio Grande do Norte, Natal, Rio Grande Do Norte, Brazil

2 Laboratório de Ecologia Humana, Departamento de Ecologia, Universidade Federal do Rio Grande do Norte, Natal, Rio Grande Do Norte, Brazil

3 CoLab - Individual Differences and Social Strategies Lab. Departamento de Psicobiologia, Universidade Federal do Rio Grande do Norte, Natal, Rio Grande Do Norte, Brazil

* Corresponding author $\bowtie$. E-mail address: FN (vivinunes@msn.com), PML (pmaccord@gmail.com), RGF (rgferreira@ymail.com)
} 


\section{SIGNIFICANCE STATEMENT}

In Anthropocene, loss of habitat tends to approximate human and nonhuman primates, originating and/or intensifying interactions. Our manuscript reviews all existent published articles (up until the date) with an Ethnoprimatology approach in Brazil, a country with the highest primate biodiversity in the world and highly vulnerable to deforestation. Besides compiling useful information for Neotropical primate's conservation, our review is significant because we analyze and interpret variables that might be modulating interactions (i.e., type of human settlement where they occur) and offer recommendations for future cross-study comparisons. We believe our discussion is plausible for opening doors for subsequent Ethnoprimatology articles in Brazil and in other places around the world.

\section{INTRODUCTION}

Approximately $70 \%$ of all terrestrial ecosystems are highly modified by human activities (Newbold et al. 2015), especially due the excessive consumption of natural resources stimulated both by human population growth and by the change in the pattern of recent consumption (Driscoll et al. 2018). In this new geological era called Anthropocene (Lewis and Maslin 1964), the loss of biodiversity is one of the main consequences of the global environmental crisis, and Earth is heading to a sixth mass extinction (Ceballos et al. 2015).

However, not all species are equally vulnerable to extinction. Species with larger brain and body, lower fecundity, larger home range, arboreal, with narrower diet breadth, and lower population size are more vulnerable (Young et al. 2016). The 504 species of the Primate order fit most of these characteristics. Thus, $60 \%$ of all primate species are endangered and most of them (over $75 \%$ ) are currently in population decline (Estrada et al. 2017; IUCN 2020). Large-scale agriculture, hunting and pet trade are listed as the main causes that disrupts and extinguishes populations (Estrada et al. 2017).

Concurrently, at least $30 \%$ of primate's species survive making persistent use of anthropogenic environments as supplementary habitat (Galán-Acedo et al. 2019). Biological characteristics of species and/or human's level of tolerance to them are discussed as factors which either facilitates or constraints the survivorship of primates in human altered landscapes (Fuentes 2012; Riley 2013; Schneider 2018).

Species with high aesthetic, economic or cultural value while alive and that do not exhibit aggressive behaviors in response to people tend to be less vulnerable to the proximity with humans (Humle and Hill 2016). For example, a Nigerian population of Sclater Monkeys (Cercophitecus sclateri) grew $36 \%$ because it inhabits a forest fragment considered sacred by the local belief system (Baker et al. 2018). Furthermore, species who do not compete with human resources also tend to be more resilient due to less potential conflicts. Conservation efforts are known to be more difficult when human communities undergo hostile in- terrelation, such as raiding of crops by wild primates (Naughton-Treves et al. 1998; Fuentes 2012), with killing of individuals as a way of reducing potential crop raiders (Sillero-Zubiri and Switzer 2001).

Nonetheless, since human settlements highly vary (i.e., places with different levels of urbanization), interactions of or proximity to certain species of primates may be more or less likely to occur depending on different types of anthropic environments. For example, terrestrial or semi-terrestrial primate's species are more resilient and prone to "monkey around" human settlements such as open areas, for locomotion and foraging (Galán-Acedo et al. 2019). On the other hand, an interaction between humans and a forestspecialist primate is unlikely in treeless areas such as highly urbanized cities, due their movement limitation that precludes them to be there in the first place. Could the "where" be the main underlying/modulating factor of human-primate relationships in Anthropocene?

Studies in Ethnoprimatology have been building a robust and accurate methodology for examining these questions (Malone et al. 2014; Palmer and Malone 2018; Bezanson and Mcnamara 2019; Mcdonald et al. 2020). Yet, even though useful to mobilize stakeholders and more effective conservation approaches for site-specific situations (Malone et al. 2014), only $1,1 \%$ of all primatological literature between 2010 and 2016 used the term anywhere in their text (Mckinney and Dore 2018).

In this article we firstly assess the state of Ethnoprimatology in Brazil (evolution and geographic distribution over the years). Besides having the largest primate biodiversity on the planet (Estrada et al. 2018), Brazil's large territory and six different biomes are increasingly vulnerable to deforestation and habitat loss (Rajão et al. 2020). Since these factors eventually induce proximity between humans and wild primates (Fuentes 2012), we also aimed to further explore the correlation between different types of human and nonhuman primates' interactions and the type of environment in which they occur. We believe using Brazil as a model, this provides an opportunity to elucidate usability and importance of Ethnoprimatology studies for conservation strategies. 


\section{MATERIAL AND METHODS}

We employed the PRISMA guidelines and model (Moher et al. 2009) for reviewing process. Searches were carried out for articles to date (2020) using the keywords (in Portuguese and English), inside the texts: [("Primates" OR "ethnoprimatology" OR "monkeys") AND ("ethno*" OR "crop raiding" OR "hunting" OR "symbolic" OR "humanprimate") AND ("brazil")] in the following databases: 1) Scientific Electronic Library online (SciELO, www.scielo.org/php/index.php), 2) Google academic (Google Scholar, https://scholar.google.com.br) 3) Portal of journals of the Coordination for the Improvement of Higher Education Personnel (Capes, www.periodicos.capes.gov.br), 4) Scopus (www.scopus.com) and 5) Web of Science (webofknowledge.com). Although we did not include the keywords "Human perception" or "Environment perception" of Primates, articles with this approach/methodology were eventually included if they cited any of the searched keywords throughout their text. In a second step, we went through all the pages of results reading the article's title. When it was not clear or had not enough information (e.g., Articles with "Amazon Primates" on its title but that could not necessarily involve Brazilian Amazon), we read their abstracts. Once our goal was a systematic survey on specifically published Ethnoprimatological research in Brazil, we excluded articles of ethnozoology or ethnography encompassing other taxa, studies focused only either on species occurrence or on population's behavioral ecology in fragments and unpublished studies, such as master's dissertations and theses. We selected studies published in scientific journals or presented in scientific meetings, specifically concerned with primates and their direct interaction with humans and/or urban settlements. We also performed convenience samples ("opportunistic sampling") incorporating studies of interest that had not appeared in the searches but by chance appeared as reference in other articles.

The selected manuscripts were carefully read. All the cited human-nonhuman primates' interaction were reckoned and considered, regardless if it was the study's main goal/result or a simple event quoted throughout the discussion. We organized the article's data per cited primate species and its conservation status, locality of the study, state, biome, type of settlement and the type interaction. Species' nomenclature was reviewed and altered according to the latest taxonomic updates (IUCN 2020). The conservation status was extracted also from the International Union for Conservation of Nature (IUCN 2020). Biome was defined according to the locality studied based on biogeographical maps.
We classified the type of settlement by considering small municipalities with less than 10,000 inhabitants (according to Brazilian Institute of Geography and Statistics Foundation, IBGE) and indigenous tribes far from large urban centers as 'Rural' and large urban centers, such as capitals, as 'Urban'. Articles that did not cite primates at species level were included only by genera (e.g., Sapajus ssp). We included articles that did not specify the state or location of the study as "Unspecified".

For the descriptive analysis, we divided the total of citations per genus (e.g., number for Alouatta citations in all articles) by the total of citations (e.g., Alouatta + Cebus + Sapajus... etc.). Next, we conducted a Chi-square analyses to test the relationship between types of interaction and a) primate genus, b) species conservation status, c) Brazilian states, d) biomes and e) type of settlements (rural vs. urban). Articles that presented an "unspecified" state, biome or species could only be included in "e)". In these analyses, we excluded the primates with a sample size less than $2 \%$ of total to avoid statistical bias. Finally, we performed a Principal Component Analysis ('prcomp' script on Program R 2015) to detect trends (latent co-variances among variables) based on the pattern of co-citation grouped by genus.

\section{RESULTS}

\section{Data-base search}

The results from all searched keywords on all databases gave us 54049 results ( $n=8$ from opportunistic sampling, see AddFile 1, Supplementary Material). This elevated number is due mainly Google Scholar platform algorithm, which finds keywords within texts, references and in an isolated way (e.g., when we searched "Hunting + Primates" we found articles on general Hunting also, not necessarily of primates) (Beel and Gipp 2009). After employing exclusion criteria, our review resulted in 36 articles.

\section{Quantitative review}

Of the 36 articles found, 18 were published in Brazilian journals, 17 in international journals and 1 (one) corresponded to a paper presented at a congress (AddFile 2, Additional File). The first Ethnoprimatological study in Brazil was published 29 years ago (Peres 1991) and there is a slow increase in the publications in the area over the years, with a peak of studies in 2017 (Figure 1). The Sapajus and Alouatta genus are the most cited, mentioned, respectively, in $46 \%$ and $38 \%$ among the 36 articles found (Figure 2). No article cited the Genus Callibela, Callimico, Mico or Leontopithecus. 


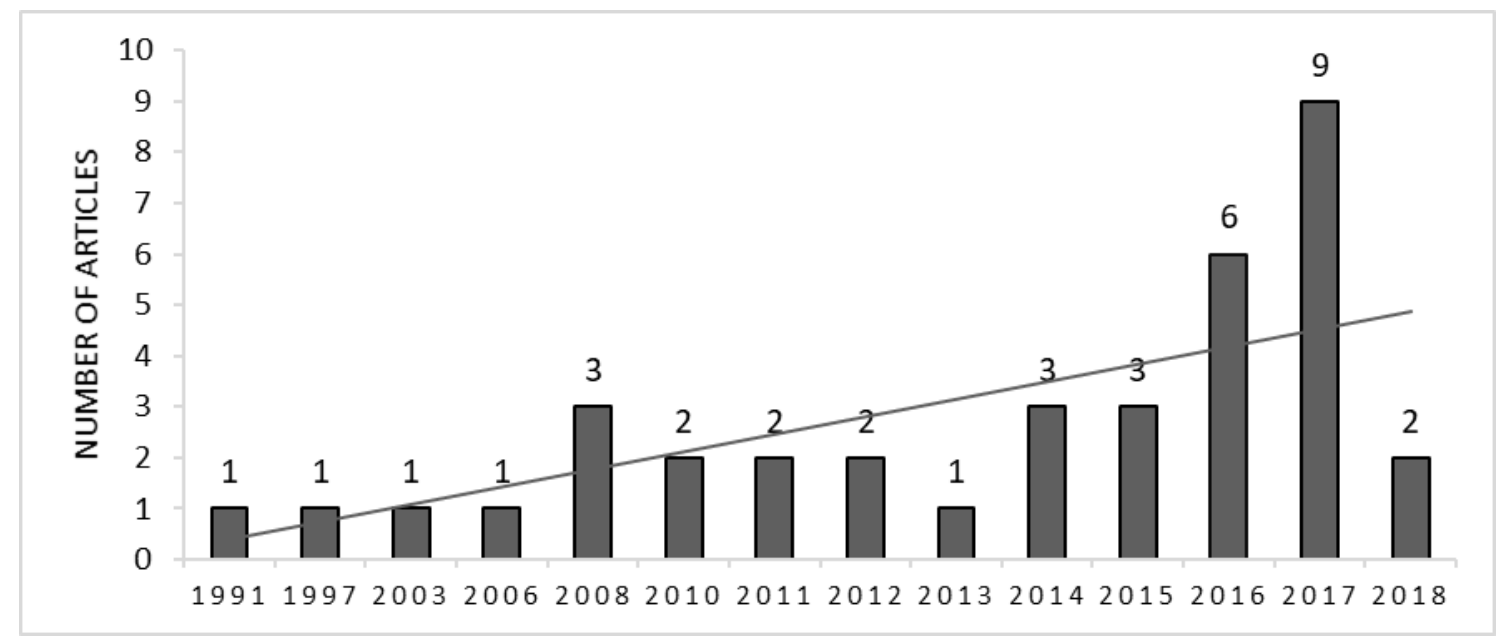

Figure 1. Total of Ethnoprimatological studies published in Brazil per year.

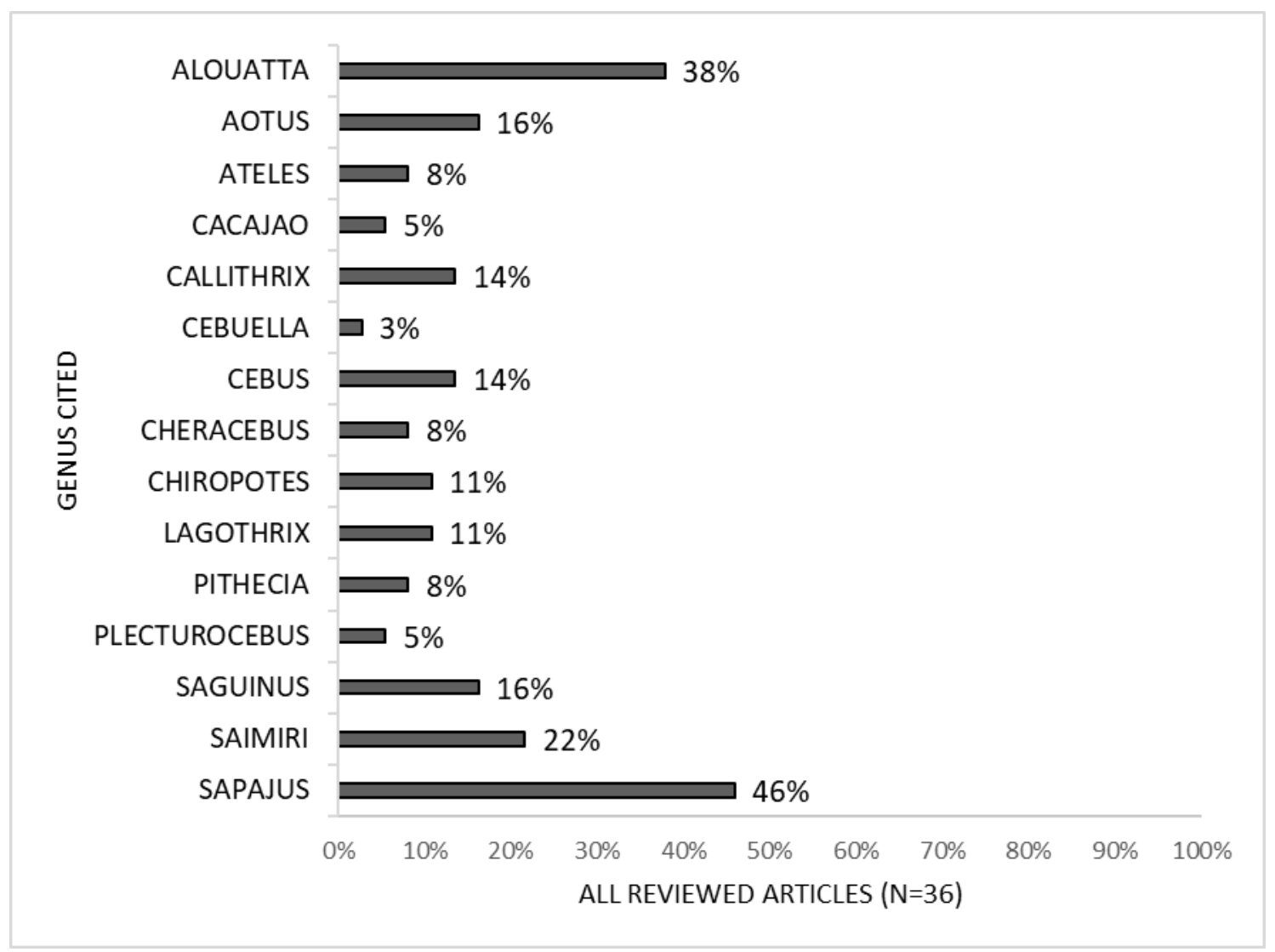

Figure 2. Relative citation of each primate genus in Ethnoprimatological articles carried out in Brazil.

The Atlantic Forest was the most studied biome ( $n=12$ articles). Only one article was found for Pampa and it involved specifically human perception of Primates and no direct interaction (Buss, Romanowski and Becker 2015). No study was found for Caatinga or Pantanal biomes. Three articles did not specify the location of human-nonhuman primate's interaction, only the state (Alves et al. 2012, 2016,
2017). Of all 27 Brazilian states, nine were identified as having none published Ethnoprimatological studies (See Add File 3 in Additional Files). Almost equal number of studies reported interactions in urban settlements $(56 \%)$ and rural areas (44\%).

The total of all different interactions between humans and Brazilian primates cited in the 36 articles was $n=171$. A major portion $(n=120)$ was de- 
scribed specifically for the Amazon Biome versus only 12 for Cerrado and 11 for the Atlantic Forest. It shall be highlighted that only two articles by the same author were responsible for 101 from those 120 cited interactions (Cormier 2003; Cormier and Cormier 2006) (See Add File 4 in Additional Files).

We distinguished 12 (twelve) different types/categories of human-primate interactions (See Table 1): Crop-raiding, Garbage foraging, Eating avoidance/Taboo (i.e. avoidance of hunting and consumption of certain primate species for reasons such as superstitious beliefs), Tourism, Home invasion, Hunting, Medicinal use, Mystical/religious/symbolic/ritualistic use, Pet, Food offering (i.e. citation of humans offering food to animals directly), Poaching (i.e. hunting activities for fun, specifically described as having no alimentary, medicinal or symbolic function) and Poisoning. Examples of how we detected types/categories of human-nonhuman primate interactions can be seen below (Table 1).

The most frequent cited/studied interaction is Hunting ( $n=64$ from 171 interactions, $64.37 \%$ of citations), followed by Mystical/Symbolic/Religious relationship ( $n=33$ from 171 interactions, 33.19\%) and Medicinal use ( $n=21,21.12 \%$ of all interactions) (See Add File 3 in Supplementary material). Although Alouatta and Sapajus are the two most studied genera, Sapajus had a greater variety of interactions ( $n=11$ from 12 possible interactions) than Alouatta (with only 7 ).

With the Chi-squared analysis (Add File 5 in Supplementary Material), we found no significant correlation between the different types of interaction and genus of the primates $\left(\chi^{2}=110.475, P=0.202\right)$. However, analyses of adjusted residuals point to a tendency of higher frequency of Food Offering towards Callitrichids (AdjR $=3,0$ ) and higher number of citations of Crop Invasion by Sapajus (AdjR $=3,2$ ). The genus of Cacajao, Cheracebus, Pithecia and Plecturocebus were excluded from the Chi-square and PCA analyzes because they are rarely mentioned $(>2 \%)$.

Chi-square analyses show significant association between Types of interactions of human-nonhuman primates and 1) the conservation status of species $\left.\left(\chi^{2}=94.248, P=0.001\right), 2\right)$ Brazilian Biomes $\left(\chi^{2}=141.167, P=0.0014\right)$ and furthermore, the context where the interactions occur: 3) Types of Human Settlement $\left(\chi^{2}=192.674, P=0.001\right)$.

Near-threatened conservation status are significant correlated with interactions of Food Offering, Garbage Foraging, Crop Raiding and Poisoning. These interactions are also correlated with Brazilian biome Cerrado. For other Brazilian Biomes, huntingtype interactions correlated with Amazon, and Poaching and Home Invasion are associated with Atlantic Forest biome (See Add File 5 Additional Files).

\section{Where Interactions Occur}

Callithrix is significantly more frequently described in urban environments (chi-squared test, $\chi^{2}=$ $589,419, P<0.001$, See Add File 5 in Additional Files). Further significant Chi-squared test between Types of Human settlement and interactions $\left(\chi^{2}=\right.$ 192.674, $P=0.001$ ) reveal that Food offering, Crop raiding, Garbage foraging and Poaching are significant correlated with urban areas, while Hunting and Poisoning interactions were correlated with a Rural type of settlement (shown in Figure 3).

\section{Patterns of Context-dependent Interac- tions}

PCA analysis reveals the 12 types of interactions can be grouped into two main factors (Add File 6 in Additional Files). The first factor encompassing interactions of Hunting, Pet, Medicinal, Mystical, Taboo and Tourism and in the second one, interactions of Food Offering, Crop Invasion, Garbage Foraging, Poaching, Poisoning and Home Invasion. Despite being almost equally cited in reviewed articles, Sapajus and Alouatta are in different components: Sapajus closer to the second axis and Alouatta in the first one (shown in Figure 4). The other primate's genera are less cited thus less sparse, forming a cluster. Overall, Aotus, Saguinus, Chiropotes and Cebus are grouped in the first factor and Callithrix, Lagothrix, Saimiri and Ateles on the second one along with Sapajus.

\section{DISCUSSION}

In this systematic review, we show that Ethnoprimatology in Brazil, as in the rest of the world (Riley 2018), is still a recent area of research. Thirty years after the publication of the first scientific paper, the total still sums only 36 published manuscripts. Despite that, 12 different types of human-nonhuman primate interactions could be discerned, and studies mentioned 15 from all 17 Brazilian primate genera (Estrada et al. 2018). The most cited ones are Sapajus and Alouatta. The largest number of published studies were conducted in the Atlantic Forest Biome, but the largest number of human-primate interactions was described in Amazon, specifically involving indigenous communities and data collected by the same author (Cormier 2003; Cormier and Cormier 2006).

Studies carried out in both Rural and Urban environment are almost equal in number but showed differences in types of interactions they describe. Although morphologically varied, which would induce multiple different human perceptions and use of them (Humle and Hill 2016), Brazilian primates are grouped in basically only two axes of human- 
Table 1. Identified human-nonhuman interactions in Brazil and examples on how they were presented/cited in some of the reviewed articles.

\begin{tabular}{cl}
\hline \hline Types/Categories identified & Example \\
\hline \hline CROP RAIDING & "We developed a simple method of quantifying the economic costs \\
& of crop feeding $(C C F)$ by brown howlers..." (Chaves et al, 2017); \\
& "The presence of capuchin monkeys was reported in 21 properties, \\
& and they raid maize crops in $71 \%$ of them." (Rocha and Fortes \\
& $2015)$ \\
& "..., he said that in addition to going down from the trees they \\
& also search the garbage. "These monkeys are mutts. They mess \\
& up in the trash and drop everything!",..." (Silveira and Silva 2017). \\
& "... for the more visitors were at the swimming pool the more \\
& food was present in the garbage bins, ... "tralizar (Sabbatini et \\
& al. 2016)
\end{tabular}

EATING AVOIDANCE/TABOO "Howler monkeys (Alouatta) had a taboo or avoidance in seven of twelve groups (58\%) ..." (Cormier and Cormier 2006)

TOURISM "Despite the density variations of A. juara and S. macrocephalus on intense use trails, possibly indicating habituation of the groups on Ecotourism. . ." (Paim et al. 2012)

HOME INVASION

HUNTING

MEDICINAL USE

MYSTICAL

PET

FOOD OFFERING

POACHING

POISONING
"Some marmosets have entered people's kitchens, service areas or even living rooms." (Rodrigues and Martinez 2014)

"The Guariba (Alouatta juara) and Cairara (Cebus unicolor) were the most representative species in number of hunted individuals,..." (Nunes et al. 2017) "Table 1 provides a list of ethnographic references to monkey hunting in Amazonia." (Cormier and Cormier 2006)

"Table 1. Primates used as remedies in traditional folk medicine." (Alves, Souto and Barboza 2017)

"Table 8.3 Primates used in magic-religious rituals or practices." (Alves et al 2012)

"... we were able to confirm the fact that some people may hunt or have primates as pets, specifically the common marmoset." (Torres et al. 2016)

"Only 2.44\% of the public provided food for the marmosets and these items were always sweet artificial products $(N=5)$ such as ice cream, popcorn, biscuits and sweets." (Leite et al. 2011)

"... in several interviews there was mention of persecution and hunting of capuchin monkeys ..." (Rocha and Fortes 2015)

"... and only $1 \%(N=1)$ of the citations were of methods harmful to the monkeys (poisoning)." (Spagnoletti et al. 2017) nonhuman interactions. According to our analysis: 1) Sapajus, Callithrix, Lagothrix, Saimiri and Ateles are related to interactions such as Poaching, Garbage Foraging and Food Offering, which tends to happen in more urbanized areas, and 2) Alouatta, Saguinus, Aotus, Chiropotes and Cebus are related to Taboo/Eating Avoidance, Medicinal Use and Mystic/Symbolic relationships, formerly occurring in rural areas and indigenous territory. This is an evidence that besides modulated by human's perception and biological characteristics of species (Fuentes 2012; Riley 2013; Schneider 2018), patterns of interactions between human-nonhuman primates might be contextdependent. 


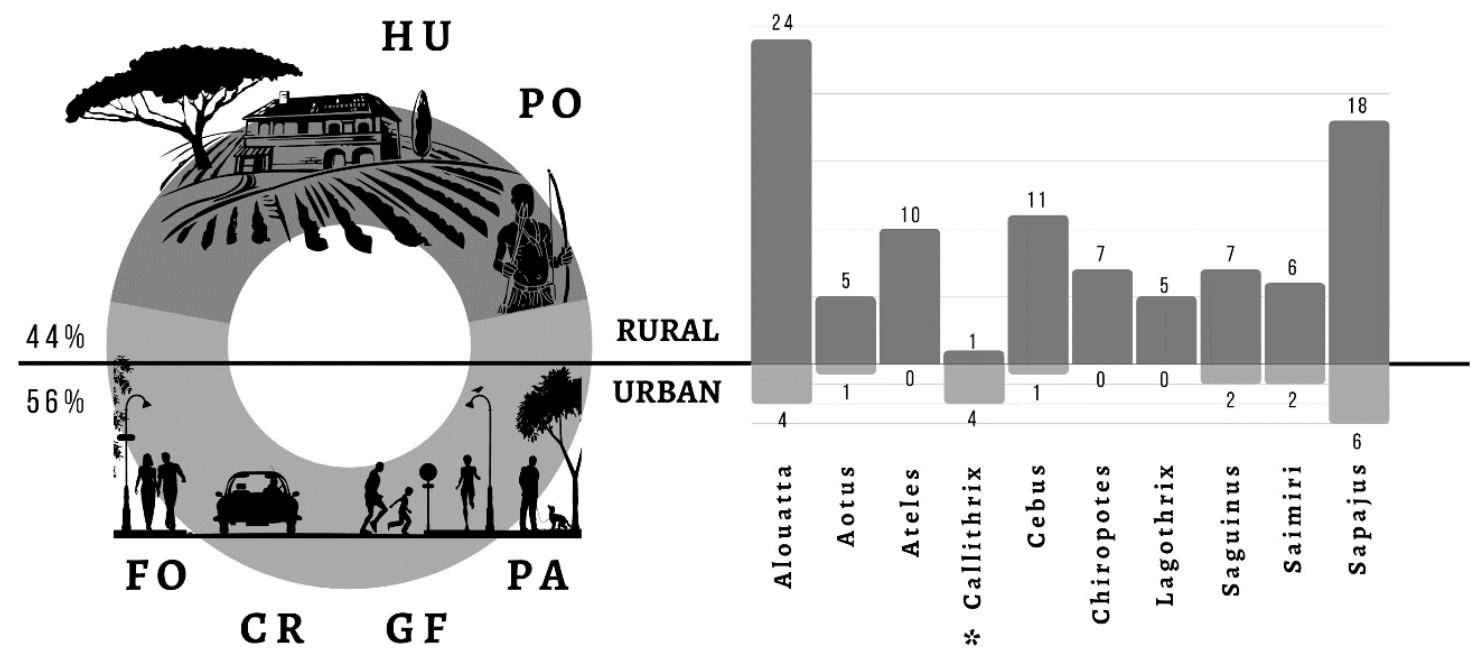

Figure 3. Illustration of found Chi-squared significant correlations: Between human settlements (Urban (56\%) and Rural (44\%), Genus of primates (Alouatta, Aotus, Ateles, Callithrix, Cebus, Chiropotes, Lagothrix, Saguinus, Saimiri and Sapajus) and six types of interactions. PO = Poisoning, FO = Food Offering, GF = Garbage Foraging, $\mathrm{CR}=$ Crop Raiding, $\mathrm{HU}=$ Hunting, $\mathrm{PA}=$ Poaching. ${ }^{*}$ Callithrix is significantly correlated with Urban settlement. Made on Canva website, based on Chi-squared results (Add File 5, Supplementary material).

For example, despite being the two most cited genus, interactions between Sapajus, Alouatta and humans take place in different contexts (rural x urban) and thus apparently differ on its aspects. Alouatta have more citations of interactions in a "symbolic" way such as Mystical beliefs and Taboo/Eating Avoidance. Those symbolic relationships seem to be particularly well-described for indigenous people (Cormier and Cormier 2006; Alves et al. 2012; Alves, Souto and Barboza 2016) and apparently absent in other human communities such as the ones in a more urbanized environment. Some of the reasons why hunting Howler monkeys for food is avoided/become a taboo are 1) Fear of Lethargy: a long due perception on their biological traits, such as being a slower animal in comparison to other species. Indigenous people avoid hunting/eating Howler monkeys because of the fear of acquiring their "laziness" (Urbani and Cormier 2014). 2) Taste: Howler monkeys' taste is not as good as other nonhuman primates' meat because they have a folivorous diet (Shepard 2002) and 3) Mystic/ritualistic reasons, such as considering howler monkeys as relatives, or fear of bad omen's (Urbani and Cormier 2014).

Those kinds of socialized norms and beliefs are known to often play a role in conservation by protecting species and natural places. In this context, current interactions of humans and Howler monkeys in Brazil at first doesn't seem to be a thread to species conservation. But the erosion of traditional beliefs and institutions have implications on this customary protection (Sasaki et al. 2010; Schneider 2018). A substantial part of the articles we found are describing human-nonhuman primate interactions in Cerrado and Amazon, worryingly, the two Brazilian biomes with higher number of deforested areas for soy and beef imports, where over $99 \%$ of it was done illegally (Annual Deforestation Report Mapbiomas 2019; da Cruz et al. 2020; Rajão et al. 2020). In indigenous reserves, higher deforestation rates can cause hunting of primates to go from sustainable to non-sustainable since it makes species either migrate towards the Indian Reserves (leading to a short-term rise in hunting game) or dwindle (Prado et al. 2012). In more urbanized areas, home range loss can cause species of primates to start invading farms/houses and/or raiding crops for subsistence (Fuentes 2012), and being viewed as pests have the most adverse effect on people's attitudes (Jones et al. 2008).

Genus such as Sapajus with generalist/opportunistic eating habits, more active and semi-terrestrial (Fragaszy et al. 2004) are known to be even more resilient to habitat disturbance than Alouatta, often having least-concern conservation status (GalánAcedo et al. 2019). Nevertheless, this higher proximity means being exposed to other manifold threats, especially since they are not protected by any symbolic beliefs. We found Sapajus have the greatest diversity of interactions with humans of all other genera, including those in more urbanized settlements 


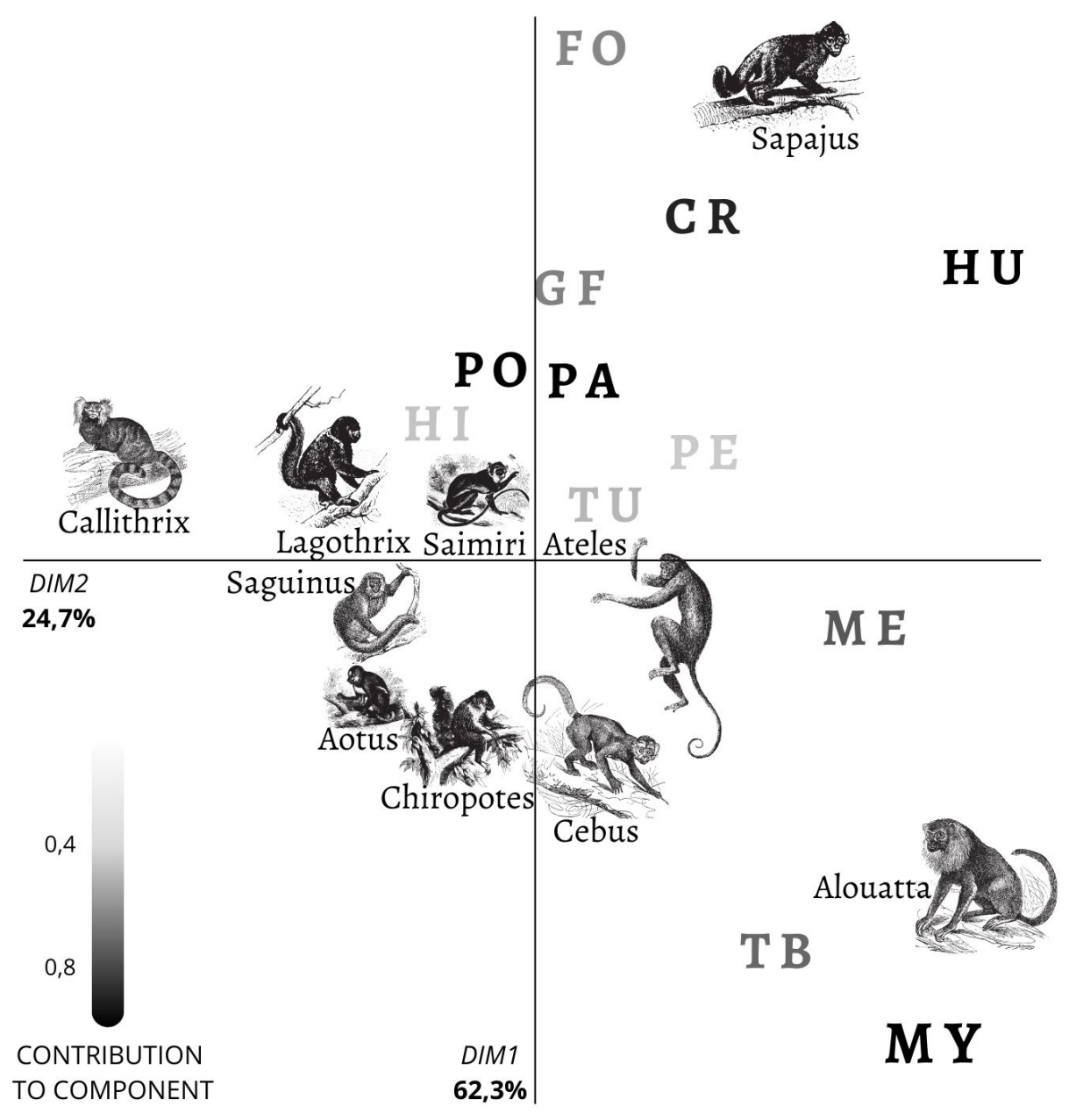

Figure 4. Biplot for Principal Component Analysis of the relationship between primate genus and types of interactions. $\mathrm{PO}=$ Poisoning, $\mathrm{FO}=$ Food Offering, $\mathrm{GF}=$ Garbage Foraging, $\mathrm{CR}=$ Crop Raiding, $\mathrm{HU}=$ Hunting, $\mathrm{HI}=$ Home Invasion, $\mathrm{PA}=$ Poaching, $\mathrm{TU}=$ Tourism, $\mathrm{PE}=$ Pet, $\mathrm{ME}=$ Medicinal, $\mathrm{TB}=$ Taboo, $\mathrm{MY}$ = Mystical/Symbolic. Made on Canva website, based on output from PCA Biplot on R Statistic (Add File 7, Additional Files).

(e.g., Garbage Foraging and Crop Invasion). Meaning they more often approach, survive and resist in human habitats making use of such environments as a possible and convenient source of food and a supplementary habitat (McKinney 2014) thus exposed to a wider range of possible interactions, including the ones that are negative.

Although not considered pests in Piauí, and poisoning events rarely mentioned (Spagnoletti et al. 2017), persecution, hunting and illegal pet trade of Capuchins were cited in several interviews in a study with communities around a Hydroelectric Power Plant on the Atlantic forest's portion of Rio Grande do Sul (Rocha and Fortes 2015). That shows even though people often tolerate proximity to capuchin monkeys, it may eventually involve some type of retaliation and it has been shown that fatal in- teractions can lead to the extermination of the local population and affect the species' conservation status (Hockings and Mclennan 2016).

In terms of retaliation, small-sized primates with non-threatening behavior/appearance have a higher likelihood of being viewed in a positive way by people (Humle and Hill 2016). For Brazilian primates, species of Callithrix genus appeared significantly more in Urban than Rural located studies and even though cited for Home invasion, it had no registered direct negative interactions with people (e.g., hunting). In contrast, the interactions involved Food offering and Pet keeping. Therefore, urban accidents of marmosets being run over by cars and attacked by domestic animals are pointed out (Rodrigues and Martinez 2014) and they are also the most found primate in Rescue and Rehabilitation Centers in Brazil, victims of illegal 
pet trade (Levacov et al. 2007).

It can be concluded that human-nonhuman primate proximity does not always have to involve "antipathy" to be problematic, especially if in urbanized areas. In other words, biological characteristics of species and human's perception of them does influence/modulate their survival in Anthropocene during land-transformation and habitat loss, but environment's context represents the final stroke of population survival. Although urbanized fragments can provide enough food and resources for some primate populations, allowing them to persist in human-modified habitats (Corrêa et al. 2018; Galán-acedo et al. 2019), erosion of traditional beliefs and lack of general education are pitfalls. In times of yellow fever outbreak in Brazil, for example, a large number of howler monkeys on city fragments in Rio Grande do Sul state were persecuted, poisoned and killed for the mistaken fear of direct disease transmission (BiccaMarques and Freitas 2010; Freitas 2011).

In this context, Ethnoprimatology has been a useful instrument to monitor communities' perceptions and proximity's context with primates (Voltolini et al. 2018), showing that Environment Education strategies are a very fundamental element in order to achieve conservation goals. A more detailed focus on whether the interactions varies in different contexts may offer important insights to management decisions. Alliances between conservation biologists, government agencies, informal institutions and holders of traditional beliefs and practices such as indigenous people must be considered important and acknowledged fairly.

For instance, a program to cover capuchin monkey's protection would need to consider introducing educational plans for rural populations on more advantageous methods to deter or control crop raiding or garbage foraging by wild populations, even if isn't generating direct conflict in some type of way. Changes in rainfall/seasons with further climate change might increase frequency and intensity of raiding of crops and other urban invasions (Lee and Priston 2005). Likewise, either reinstalling or sharing local symbolic beliefs with general population might be of value for Howler monkeys' conservation programs and Callithrix would benefit from campaigns against urban food offering and illegal pet trade.

Due low sampling and less information, it is unreliable addressing any directions for other primate genera. Although, it is important to note that a proximity to human communities implies a certain degree of habitat modification, and some specialized species are highly dependent on their habitat. The fact that some other primates such as Cacajao and Plecturocebus were less mentioned in articles might be related to behavioral specialization and endemism
(Soini 1982; Barnett et al. 2013). Since there is no evidence of anthropic land use for at least $70 \%$ of the primates on Earth (Galán-Acedo et al. 2019) and consequently human-proximity the other Brazilian primate genus absent on our review (Callibela, Callimico, Mico and Leontopithecus) might fall under this case. But the fact that some of the reviewed articles cited hunting activities of Pithecia vanzolinii (Nunes et al. 2017), which has conservation status as "Data Deficient" (IUCN 2020) shows that while researchers may often lack information of species living in very remote areas and small populations, human communities sharing close territory with these species can be a convenient source of information. The use of indirect evidence (i.e. local's Traditional Ecological Knowledge) has proved to be a useful integrative research tool in primatology, especially when discovering a new species or the survival of one declared extinct (Rossi et al. 2018).

In view of increasing relaxation in environmental protection laws in Brazil and the consequent irregularity in general deforestation (Estrada et al. 2018; Artaxo 2019) critical assessment and incorporation of new approaches to biodiversity conservation is essential and somewhat an emergency (Bezanson and Mcnamara 2018; Estrada et al. 2018). Thus, disregarding the use of anthropic environments by primate species as well as species relationship and proximity with local human communities, when developing new strategies and projects of conservation, may handicap conservation strategies (Lee 2010) while also representing risks of emergence of new infectious diseases (Buss, Romanowski and Becker 2015; Garcia 2017; Roe et al. 2020).

However, cross-study comparisons must be done with care. For example, in this review we aimed to distinguish Poaching (i.e., for fun) from general Hunting (i.e., for food) whenever we could assess this information on studies, but few of them were specific. Such as, some mentioned "Medicinal use" of primates, what evidently implies "Hunting" in the first place. This may have caused a bias, especially on qualitative analysis. We suggest future studies to detail and distinguish occurrences carefully. If it is for food, for fun, for medicinal use, for religious ceremonies, for retaliation/protection purposes (e.g., crop raiding or home invasion), for pet trade and/or wildlife trafficking etc. In addition, when describing Symbolic/Mystic relationships, specify whether it involves direct or indirect use or perception of species. For example, if primates are protected by being considered sacred or if their body parts are used in rituals, which would also imply hunting. That would shed further light on contexts of human and nonhuman primate's different relationships, such whether conflict comes from a human's subsistence matter or only intolerance. 
We also strongly advise future research to detail location of study at closer coordinates as possible, to facilitate future use and implementation of this information on national-wide conservation strategies. And perhaps serving on further analyses on types of interactions and biomes' fragmentation, urbanization level of human's settlement and overall context where they occur.

Very importantly, indigenous communities should be considered as a distinct group, as their use of and relationship with primates differ historical and traditionally from other human communities (Cormier and Cormier 2006). For example, the Guajá people hunt primates for food and take the young offspring as "pet gifts" for the children (Cormier 2003). Once pet, that individual primate automatically ceases to be seen as "Food" and becomes "Taboo". When they reach sexual maturity and runs away to the forest, it goes back to being vulnerable to hunting activities for food or medicinal use (Garcia 2018). Thus, since other human communities rarely have two or more discrepant types of relationship with the same species such as this, a valid cross-comparison with types of interactions that indigenous people have with primates is unlikely.

We believe apart from having fewer primate species in comparison to Amazon and Atlantic Forest biomes (Keirulff et al. 2007), the lack of Ethnoprimatology studies for Pantanal and Caatinga are overall symptomatic. There is a recurrent scientific low-priority and negligence for both biomes, where the same pattern was found, for example, in a review for Coleoptera Biodiversity and Ecological Restoration studies (Lewinsohn, Freitas and Prado 2005; Laurance and Garcia 2020). Coincidentally or not, Amazon Biome houses the largest extent of protected areas in contrast to others such Caatinga (with less than $4 \%$ ), a fragile dry tropical whereas $50 \%$ of its territory has been neglected by biodiversity surveys (Santos et al. 2011; Oliveira et al. 2017). Hence, our review adds to one more example elucidating the urgency to fill research gaps in these biomes to better base national conservation strategies. Finally, it is relevant to note that since Ethnoprimatology is still a recent area of research, data of interest might have been left out of this review due lack of publishing, not-well defined key-words and unclear methodologies. Field primatologists, typically working with primates' species in fragments next to rural communities, often come across information that may represent a valuable for developing conservations strategies. Communities living close to wildlife are well placed, they are able to early detect and report and so help prevent biodiversity threats such as illegal trade. We suggest studies, even the ones focused on a more ecological or biogeographical approach, to make descriptions of humanprimate interactions, while assuring enough signaliza- tion by using correct terms such as "Ethnoprimatology", "human-nonhuman primate" relationships or interactions.

\section{CONCLUSION}

In Brazil, studies published in scientific literature with a clear Ethnoprimatological approach are still scarce, only 36 up to 2020 . There is a lack of published studies for two out of five Biomes of Brazil, Caatinga and Pantanal. According to our review and analysis, human-nonhuman primates' interactions in Brazil are context-dependent and follow a pattern that could be discerned into two axes. One involving interaction in more urbanized settlements and includes food offering by people and crop raiding and garbage foraging by primates. Those interactions may also involve some form of retaliation such as poisoning, eventual accidents with cars and domestic animals and illegal pet trade and keeping. The second one, in rural settlements, involving mystic and symbolic relationships. In other words, "Monkeying around" Anthropocene differ depending on primates' genus and types of human settlement. Maintain and explore the growing curve of Ethnoprimatological studies not only in Brazil but worldwide can aggregate information about causes and patterns and so consequences of each and individual human-nonhuman primates' proximity. Thus, help better base successful conservation strategies.

\section{ACKNOWLEDGEMENT}

We thank Dra Romari Alejandra Martinez Montano and Dr Raul Fernandes Dantas Salles for their comments and contributions, helping critically revise the paper in its draft phase. This study was financed in part by the Coordenação de Aperfeiçoamento de Pessoal de Nível Superior - Brasil (CAPES) - Finance Code 001.

\section{DATA AVAILABILITY}

The data used to support the findings of this study are available through open-data in the supplementary material.

\section{CONFLICT OF INTEREST}

The authors have no conflicts of interest to declare.

\section{CONTRIBUTION STATEMENT}

Conceived of the presented idea: VFN, RGF, PMC

Carried out the data gathering: VFN 
Carried out the data analysis: VFN

Wrote the first draft of the manuscript: VFN, RGF, PMC

Review and final write of the manuscript: VFN, RGF Supervision: VFN, RGF, PMC

\section{REFERENCES}

Alves RRN, Souto WMS, Barboza RRD (2012) Primates in Traditional Folk Medicine: World Overview. In: Animals in Traditional Folk Medicine. Oxford, UK: Blackwell Publishing Ltd, pp. 135-170.

Alves RRN, Barboza RRD, Souto WMS (2017) Primates in Traditional Folk Medicine. The International Encyclopedia of Primatology doi:10.1002/9781119179313.wbprim0168.

Alves RRN, Souto WMS and Barboza RRD (2016) The Role of Nonhuman Primates in Religious and Folk Medicine Beliefs. In Ethnoprimatology: Primate conservation in the 21st century doi: 10.1007/978-3-319-30469-4.

Artaxo P (2019) Working together for Amazonia. Science doi: 10.1126/science.aaw6986.

Baker LR, Tanimola AA, Olubode OS (2018) Complexities of local cultural protection in conservation: The case of an Endangered African primate and forest groves protected by social taboos. Oryx 52:262-27.

Barnett AA, Bowler M, Bezerra BM, Defler TR (2013) Ecology and behavior of uacaris (genus Cacajao). Evolutionary Biology Conservation of Titis, Sakis and Uacaris doi:10.1017/cbo9781139034210.020.

Beel J, Gipp B (2009) Google Scholar's Ranking Algorithm: An Introductory Overview. In: Larsen B, Leta J (eds) Proceedings of the 12th International Conference on Scientometrics and Informetrics, pp. 230-241.

Bezanson M, Mcnamara A (2019) The what and where of primate field research may be failing primate conservation. Evolutionary Anthropology 28:166-178.

Bicca-Marques JC, de Freitas DS (2010) The role of monkeys, mosquitoes, and humans in the occurrence of a yellow fever outbreak in a fragmented landscape in south brazil: Protecting howler monkeys is a matter of public health. Tropical Conservation Science doi:10.1177/194008291000300107.
Buss G, Romanowski HP, Becker FG (2015) O bugio que habita a mata e a mente dos moradores de Itapuã - Uma análise de percepção ambiental no entorno do Parque Estadual de Itapuã, Viamão, RS. Revista Biociências 21:14-28.

Ceballos G, Ehrlich PR, Barnosky AD, García A, Pringle RM, Palmer TM (2015) Accelerated modern human-induced species losses: Entering the sixth mass extinction. Science Advances $1: 9-13$

Cormier L, Cormier L (2006) A Preliminary Review of Neotropical Primates in the Subsistence and Symbolism of Indigenous Lowland South American Peoples. Ecological and Environmental Anthropology 2:14-32.

Cormier LA (2003) Chapter 4: Monkey as food, monkey as child: Guajá symbolic cannibalism. In: Cormier LA (ed) Kinship with Monkeys: The Guaja Foragers of Eastern Amazonia. Columbia University Press, pp. 63-84.

Corrêa FM, Chaves OM, Printes RC, Romanowski HP (2018) Surviving in the urban-rural interface: Feeding and ranging behavior of brown howlers (Alouatta guariba clamitans) in an urban fragment in southern Brazil. American Journal of Primatology doi:10.1002/ajp.22865.

da Cruz DC, Benayas JMR, Ferreira GC, Santos SR, Schwartz G (2020) An overview of forest loss and restoration in the Brazilian Amazon. New Forests doi:10.1007/s11056-020-09777-3.

Driscoll DA, Bland LM, Bryan BA, Newsome TM, Nicholson E, Ritchie EG, Doherty TS (2018) A biodiversity-crisis hierarchy to evaluate and refine conservation indicators. Natural Ecology and Evolution 2:775-781.

Estrada A, Garber PA, Rylands AB, Roos C, Fernandez-Duque E, Fiore AD, Nekaris KA, Nijman V, Heymann EW, Lambert JE, Rovero F, Barelli C, Setchell JM, Gillespie TR, Mittermeier RA, Arregoitia LV, Guinea M, Gouveia S, Dobrovolski R, Shanee S, Shanee N, Boyle SA, Fuentes A, Mackinnon KC, Amato KR, Meyer ALS, Wich S, Sussman RW, Pan R, Kone I, Li B (2017) Impending extinction crisis of the world's primates: Why primates matter. Science Advances doi: 10.1126/sciadv.1600946.

Estrada A, Garber PA, Mittermeier RA, Wich S, Gouveia S, Dobrovolski R, Nekaris KAI, Nijman V, Rylands AB, Maisels F, Williamson EA, Bicca-Marques J, Fuentes A, Jerusalinsky L, Johnson S, de Melo FR, Oliveira L, Schwitzer C, Ross C, Cheyne SM, Kierulff MCM, Raharivololona B, Talebi M, Ratsimbazafy J, 
Supriatna J, Boonratana R, Wedana M, Setiawan A (2018) Primates in peril: The significance of Brazil, Madagascar, Indonesia and the Democratic Republic of the Congo for global primate conservation. PeerJ Life and Environment doi: $10.7717 /$ peerj.4869.

Fragaszy DM, Visalbergui E, Fedigan LM (2004) The complete capuchin: the biology of the genus Cebus. Cambridge; New York: Cambridge University Press, USA.

Fuentes A (2006) Human-Nonhuman Primate Interconnections and Their Relevance HumanNonhuman Primate Interconnections and Their Relevance to Anthropology to Anthropology. Ecological and Environmental Anthropology $2: 2$.

Garber PA, McKenney A, Bartling-John E, BiccaMarques JC, de la Fuente MF, Abreu F, Schiel N, Souto A, Phillips KA (2020) Life in a harsh environment: The effects of age, sex, reproductive condition, and season on hair cortisol concentration in a wild non-human primate. PeerJ doi: $10.7717 /$ peerj. 9365 .

Galán-Acedo C, Arroyo-Rodríguez V, Andresen E, Arregoitia LV, Veja E, Peres CA, Ewers RB (2019) The conservation value of human-modified landscapes for the world's primates. Nature Communications 10:1-8.

Garcia U (2018) Macacos também choram, ou esboço para um conceito ameríndio de espécie. Revista do Instituto de Estudos Brasileiros doi: 10.11606/issn.2316-901x.v0i69p179-204.

Hockings KJ, Mclenna MR (2016) Problematic Primate Behaviour in Agricultural Landscapes: Chimpanzees as 'Pests' and 'Predators' In. Managing human-orangutan relationships in rehabilitation doi: 10.1007/978-3-319-30469-4_8.

Humle T, Hill C (2016) People-primate interactions: implications for primate conservation. In: Wich SA, Marsall A (eds) Introduction to Primate Conservation. Oxford University Press, pp. 219-240.

Jones JPG, Andriamarovololona MM, Hockley N (2008) The importance of taboos and social norms to conservation in Madagascar. Conservation Biology doi: 10.1111/j.15231739.2008.00970.x.

Keirulff MCM, Procópio-de-Oliveira P, Martins CS, Valladares-Padua CB, Porfirio S, de Oliveira MM, Rylands AB, Bezerra ARGF (2007) Manejo para a conservação de primatas brasileiros. In: BiccaMarques JC (ed) A Primatologia no Brasil, Porto Alegre, RS, Brasil.
Laurance SGW, Garcia LC (2020) Ecological restoration in Brazilian biomes: Identifying advances and gaps. Forest Ecology and Management doi: 10.1016/j.foreco.2019.117802.

Lee P, Priston N (2005) Human attitudes to primates: Perceptions of pests, conflict and consequences for primate conservation. Commensalism and Conflict: The Human-Primate Interface doi: 10.1002/047001539X.ch1.

Lee PC (2010) Sharing Space: Can ethnoprimatology contribute to the survival of nonhuman primates in human-dominated globalized landscapes? American Journal of Primatology doi: 10.1002 /ajp.20789.

Leite GC, Duarte M, Young RJ (2011) Human-marmoset interactions in a city park. Applied Animal Behaviour Science doi:10.1016/j.applanim.2011.03.013.

Levacov D, Jerusalinsky L, Fialho M (2007) Tráfico nacional de primatas: Táxons, origens, destinos. In: Brazilian Primatological Congress, VII, 2007. Anais Belo Horizonte, p. 87.

Lewis SL, Maslin MA (1964) Defining the Anthropocene. Nature doi:10.1038/nature14258.

Lewinsohn TM, Freitas AVL, Prado PI (2005) Conservation of terrestrial invertebrates and their habitats in Brazil. Conservation Biology doi: 10.1111/j.1523-1739.2005.00682.x.

Malone NM, Wade A, Fuentes A, Riley EP (2014) Ethnoprimatology: Critical interdisciplinarity and multispecies approaches in anthropology. Critique of Anthropology doi: 10.1177/0308275X13510188.

Mcdonald RI, Mansur AV, Ascensão F, Colbert M, Crossman K, Emlqvist T, Gonzalez A, Güneralp B, Haase D, Hamann M, Hillel O, Huang K, Kahnt B, Maddox D, Pacheco A, Pereira HM, Seto KC, Simkin R, Walsh B, Werner AS, Ziter C (2020) Research gaps in knowledge of the impact of urban growth on biodiversity. Nature Sustainability $3: 16-24$

McKinney T (2014) Species-Specific Responses to Tourist Interactions by White-Faced Capuchins (Cebus imitator) and Mantled Howlers (Alouatta palliata) in a Costa Rican Wildlife Refuge. International Journal of Primatology doi: 10.1007/s10764-014-9769-1.

McKinney T, Dore KM (2018) The State of Ethnoprimatology: Its Use and Potential in Today's Primate Research. International Journal of Primatology doi: 10.1007/s10764-017-0012-8. 
Moher D, Liberati A, Tetzlaff J, Altman DG, Prisma Group (2009) Preferred Reporting Items for Systematic Reviews and Meta-Analyses: The PRISMA Statement. International Journal of Surgery doi: 10.1371/journal.pmed.1000097.

Moraes B, Razgour O, Souza-Alves JP, Boubli JP, Bezerra B (2020) Habitat suitability for primate conservation in north-east Brazil. Oryx doi: 10.1017/S0030605319001388.

Naughton-Treves L, Treves A, Chapman C, Wrangham R (1998) Temporal patterns of crop raiding by primates: linking food availability in croplands and adjacent forest. Journal of Applied Ecology doi: 10.1046/j.1365-2664.1998.3540596.x..

Newbold T, Hudson LN, Hill SLL, Contu S, Lysenko I, Senior RA, Börger L, Bennett DJ, Choimes A, Collen B, Day J, De Palma A, Díaz S, Echeverria-Londoño S, Edgar MJ, Feldman A, Garon M, Harrison MLK, Alhusseini T, Ingram DJ, Itescu Y, Kattge J, Kemp V, Kirkpatrick L, Kleyer M, Correia DLP, Martin CD, Meiri S, Novosolov M, Pan Y, Phillips HRP, Purves DW, Robinson A, Simpson J, Tuck SL, Weiher E, White HJ, Ewers RM, Mace GM, Scharlemann JPW, Purvis A (2015) Global effects of land use on local terrestrial biodiversity. Nature 520:45-50.

Nunes AV, Vilela JS, Saldo PA, Santos BA, Fischer E (2017) Conhecimento e uso de primatas por uma população extrativista no Vale do Juruá, Amazônia. Biodiversidade Brasileira 7:123-132.

Oliveira U, Soares-Filho BS, Paglia AP, Brescovit AD, De Carvalho CJB, Silva DP, Rezende DT, Leite FSF, Batista JAN, Barbosa JPPP, Stehmann JR, Ascher JS, De Vasconcelos MF, De Marco P, Löwenberg-Neto P, Ferro VG, Santos AJ (2017) Biodiversity conservation gaps in the Brazilian protected areas. Scientific Reports doi: 10.1038/s41598-017-08707-2.

Paim FP, Aquino SP, Valsecchi J (2012) Does ecotourism activity affect primates in Mamirauá Reserve? Uakari doi: 10.31420/uakari.v8i2.127.

Palmer A, Malone N (2018) Extending Ethnoprimatology: Human-Alloprimate Relationships in Managed Settings. International Journal of Primatology 39:831-851

Peres C (1991) Humboldt's woolly monkeys decimated by hunting in Amazonia. Oryx 25:89-95.

Prado HM, Forline LC, Kipnis R (2012) Hunting practices among the Awá-Guajá: towards a long-term analysis of sustainability in an Amazonian indigenous community. Boletim do Museu Paraense Emílio Goeldi Ciências Humanas 7:479-491.
Rajão R, Soares-Filho B, Nunes F, Börner J, Machado L, Assis D, Oliveira A, Pinto L, Ribeiro V, Rausch L, Gibbs H, Figueira D (2020) The rotten apples of Brazil's agribusiness. Science 369:246-248.

RedFord K (1992) The empty forest. Bioscience doi: $10.2307 / 1311860$.

Riley EP (2013) Contemporary Primatology in Anthropology: Beyond the Epistemological Abyss. American Anthropologist 115:411-422.

Rocha LC, Fortes VB (2015) Perceptions and attitudes of rural residents towards capuchin monkeys, in the area of influence of the Dona Francisca Hydroelectric power plant, South Brazil. Ambiente e Sociedade doi: 10.1590/18094422ASOC825V1842015.

Rodrigues NN, Martinez RA (2014) Wildlife in our backyard: interactions between Wied's marmoset Callithrix kuhlii (Primates: Callithrichidae) and residents of Ilhéus, Bahia, Brazil. Wildlife Biology 20:91-96.

Roe D, Dickman A, Milner-Gulland EJ, Rihoy E, Sas-Rolfes MT (2020) Beyond banning wildlife trade: COVID-19, conservation and development. World Development doi: 10.1016/j.worlddev.2020.105121.

Rossi L, Gippoliti S, Angelici FM (2018) The role of indirect evidence and traditional ecological knowledge in the discovery and description of new ape and monkey species since 1980. Primates 59:327-337.

Santos JC, Leal IR, Almeida-Cortez JS, Fernandes GW, Tabarelli M (2011) Caatinga: The scientific negligence experienced by a dry tropical forest. Tropical Conservation Science doi: $10.1177 / 194008291100400306$.

Sabbatini G, Stammati M, Tavares MCH, Giuliani MV, Visalberghi E (2006) Interactions between humans and capuchin monkeys ( $\mathrm{Ce}$ bus libidinosus) in the Parque Nacional de Brasília, Brazil. Applied Animal Behavior. doi: 10.1016/j.applanim.2005.07.002.

Sasaki K, Sasaki Y, Fox SF (2010) Endangered traditional beliefs in Japan: Influences on snake conservation. Herpetological Conservation and Biology 5:474-485.

Schneider H (2018) What role for culture in conservation? Oryx doi: 10.1017/S0030605318000248.

Shepard GH (2002) Primates in Matsigenka Subsistence and World View. In: A Fuentes, LD Wolfe (eds) Primates Face to Face: The Conservation 
Implications of Human-nonhuman Primate Interconnections. Cambridge University Press, pp. 101-136.

Sillero-Zubiri C, Switzer D (2001) Crop raiding primates: Searching for alternative, humane ways to resolve conflict with farmers in Africa. People and Wildlife Initiative. Conservation Research Unit, Oxford University, USA.

Spagnoletti N, Cardoso TCM, Fragaszy D, Izar P (2017) Coexistence Between Humans and Capuchins (Sapajus libidinosus): Comparing Observational Data with Farmers' Perceptions of Crop Losses. International Journal of Primatology doi: 10.1007/s10764-016-9926-9.

Torres EUJ, Valença-Montenegro MM, de Castro CSS (2016) Local Ecological Knowledge about Endangered Primates in a Rural Community in Paraíba, Brazil. Folia Primatologica 87:262-277.

Oliveira U, Soares-Filho BS, Paglia AP, Brescovit AD, De Carvalho CJB, Silva DP, Rezende DT, Leite FSF, Batista JAN, Barbosa JPPP, Stehmann JR, Ascher JS, De Vasconcelos MF, De Marco P, Löwenberg-Neto P, Ferro VG, Santos AJ (2017) Biodiversity conser- vation gaps in the Brazilian protected areas. Scientific Reports doi: 10.1038/s41598-017-08707-2.

Urbani B, Cormier LA (2014) The Ethnoprimatology of the Howler Monkeys (Alouatta spp.): From Past to Present. Howler Monkeys doi: 10.1007/978-1-4939-1960-4_10.

Voltolini JC, Paulista EU, Claro R (2018) Percepção ambiental dos moradores do entorno da Mata do Bugio sobre bugios-ruivos Alouatta guariba clamitans Cabrera 1940, em Taubaté, SP. Revista Biociências 23:54-64.

Young HS, McCauley DJ, Galetti M, Dirzo R (2016) Patterns, Causes, and Consequences of Anthropocene Defaunation. Annual Review of Ecology, Evolution, and Systematics doi:10.1146/annurevecolsys-112414-054142.

Received: 24 December 2020

Accepted: 29 April 2021

Published: 03 May 2021 


\section{Additional Files}

Add File 1. Keywords/Results found per Searchbase.

\begin{tabular}{|c|c|c|c|c|c|c|}
\hline Order of search & & & Platform & & & \\
\hline $\begin{array}{c}\text { Search dates } \\
\mathrm{MM} / \mathrm{DD} / \mathrm{YEAR}\end{array}$ & Keywords & Scielo & $\begin{array}{l}\text { Google } \\
\text { Schoolar }\end{array}$ & $\begin{array}{c}\text { Periódicos } \\
\text { CAPES }\end{array}$ & SCOPUS & $\begin{array}{l}\text { Web of } \\
\text { Science }\end{array}$ \\
\hline $04 / 20 / 2020$ & $\begin{array}{c}\text { etnoprimatologia; } \\
\text { brasil }\end{array}$ & 1 & 46 & 3 & 0 & 1 \\
\hline $04 / 30 / 2020$ & $\begin{array}{c}\text { ethnoprimatology; } \\
\text { brazil }\end{array}$ & 1 & 456 & 20 & 5 & 1 \\
\hline Read & & 1 & 46 & 1 & 0 & 0 \\
\hline חרכת?/ כת/ & $\begin{array}{c}\text { ethno*; primates; } \\
\text { brazil }\end{array}$ & 4 & 2040 & 0 & 8 & 9 \\
\hline $00 / 02 / 2020$ & $\begin{array}{c}\text { etno*; primatas; } \\
\text { brasil }\end{array}$ & 0 & 0 & 0 & 0 & 0 \\
\hline Read & & 0 & 5 & 0 & 3 & 0 \\
\hline 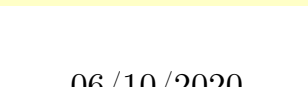 & $\begin{array}{c}\text { hunting; primates; } \\
\text { brazil }\end{array}$ & 3 & 14900 & 0 & 41 & 30 \\
\hline $00 / 10 / 2020$ & $\begin{array}{c}\text { caça; primatas; macacos; } \\
\text { brasil }\end{array}$ & 1 & 6408 & 0 & 0 & 0 \\
\hline Read & & 0 & 18 & 0 & 0 & 0 \\
\hline ח20/ & $\begin{array}{c}\text { crop raiding; primates; } \\
\text { brazil }\end{array}$ & 0 & 2220 & 0 & 1 & 1 \\
\hline $00 / 10 / 2020$ & $\begin{array}{l}\text { invasão; primatas; } \\
\text { brasil }\end{array}$ & 0 & 0 & 0 & 0 & 0 \\
\hline Read & & 0 & 3 & 0 & 0 & 0 \\
\hline 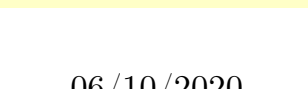 & $\begin{array}{l}\text { symbolic; primates; } \\
\text { brazil }\end{array}$ & 0 & 19300 & 0 & 0 & 0 \\
\hline $00 / 10 / 2020$ & $\begin{array}{c}\text { simbolismo; primatas; } \\
\text { brasil }\end{array}$ & 0 & 1070 & 0 & 0 & 0 \\
\hline Read & & 0 & 0 & 0 & 0 & 0 \\
\hline / & $\begin{array}{c}\text { human-primate interaction; } \\
\text { brazil }\end{array}$ & 0 & 7200 & 0 & 1 & 11 \\
\hline $00 / 10 / 2020$ & $\begin{array}{c}\text { relação humanos macacos; } \\
\text { brasil }\end{array}$ & 7 & 252 & 0 & 0 & 0 \\
\hline Read & & 0 & 3 & 0 & 0 & 0 \\
\hline $\begin{array}{l}\text { Opportunistic } \\
\text { sampling }\end{array}$ & & 8 & & & & \\
\hline Total fully read & & 56 & & & & \\
\hline $\begin{array}{c}\text { Total } \\
\text { incorporated } \\
\text { in review }\end{array}$ & & 36 & & & & \\
\hline
\end{tabular}


Add File 2. Articles Reviewed.

\begin{tabular}{|c|c|c|c|c|}
\hline Year & Reference & Type & Journal & Environment \\
\hline 2006 & Cornier 2006 & Article & Ecological and Environmental Anthropology & Rural \\
\hline 2014 & $\begin{array}{l}\text { Albuquerque and } \\
\text { Oliveira } 2014\end{array}$ & Article & A Primatologia no Brasil & Urban \\
\hline 2016 & Rapchan 2016 & Article & Iluminuras & Urban \\
\hline 2018 & Garcia 2018 & Article & Revista do Instituto de Estudos Brasileiros & Rural \\
\hline 2017 & de Ameida 2017 & Article & Revista Biociências & Urban \\
\hline 2014 & Suzin 2014 & Annal & III Encontro de iniciação Científica da Unila & Urban \\
\hline 2015 & Buss 2015 & Article & Revista Biociências & Urban \\
\hline 2015 & Rocha 2015 & Article & Ambiente e Sociedade & Rural \\
\hline 2003 & Cornier 2003 & Chapter & $\begin{array}{l}\text { Journal of the Society for the Anthropology } \\
\text { of Lowland South America }\end{array}$ & Rural \\
\hline 2017 & Spagnoletti 2017 & Article & International Journal of Primatology & Rural \\
\hline 2017 & Suzin 2017 & Article & International Journal of Primatology & Urban \\
\hline 2017 & Batista 2017 & Article & Ethnoscientia & Rural \\
\hline 2016 & Torres 2016 & Article & Folia Primatologica & Rural \\
\hline 2008 & Sabbatini 2008 & Article & Brazilian Journal of Biology & Urban \\
\hline 2008 & de Freitas 2008 & Article & Revista Brasileira de Zoologia & Urban \\
\hline 2016 & Chaves 2016 & Article & International Journal of Primatology & Urban \\
\hline 2016 & $\begin{array}{l}\text { Rapchan and } \\
\text { Neves } 2016\end{array}$ & Article & Teoria e Cultura & Rural \\
\hline 2016 & Waller et al. 2016 & Chapter & $\begin{array}{l}\text { Ethoprimatology: Primate Conservation } \\
\text { in the 21st century }\end{array}$ & unspecified \\
\hline 2012 & Alves et al. 2012 & Article & Animals in Traditional Folk Medicine & unspecified \\
\hline 2018 & Filho et al. 2018 & Article & Ethnobiology and Conservation & Rural \\
\hline 2017 & Santos et al. 2017 & Article & Neotropical Primates & Urban \\
\hline 2010 & Saito et al. 2010 & Article & Sociedade \& Natureza & Urban \\
\hline 2006 & Sabbatini 2006 & Article & Applied Animal Behavior & Urban \\
\hline 2017 & Silveira 2017 & Article & Horizontes Antropológicos & Urban \\
\hline 2008 & Freitas et al. 2008 & Article & Revista Brasileira de Zoologia & Urban \\
\hline 2010 & Jerusalinsky et al. 2010 & Article & Iheringia, Sér. Zoologia & Urban \\
\hline 2012 & Paim et al. 2012 & Article & Uakari & Rural \\
\hline 2017 & $\begin{array}{c}\text { Araújo and } \\
\text { Liesenfeld } 2017\end{array}$ & Article & Biodiversidade Brasileira & Urban \\
\hline 2017 & Nunes et al. 2017 & Article & Biodiversidade Brasileira & Rural \\
\hline 1991 & Peres 1991 & Article & Oryx & Rural \\
\hline 2011 & Brasileiro et al. 2011 & Article & Rev. eletrônica Mestr. Educ. Ambient & Urban \\
\hline 2017 & Alves and Barboza 2017 & Chapter & The International Encyclopedia of Primatology & unspecified \\
\hline 2015 & Teixeira et al. 2015 & Article & $\begin{array}{l}\text { Wildlife Research } \\
\text { Primates in Fragments: Complexity and }\end{array}$ & Urban \\
\hline 2013 & Gordo et al. 2013 & Chapter & $\begin{array}{l}\text { Resilience, Developments in Primatology: } \\
\text { Progress and Prospects }\end{array}$ & Urban \\
\hline 1997 & Peres 1997 & Article & Folia Primatologica & Rural \\
\hline 2011 & Leite et al. 2011 & Article & Applied Animal Behavior & Urban \\
\hline 2014 & $\begin{array}{l}\text { Rodrigues and } \\
\text { Martinez } 2014\end{array}$ & Article & Wildlife Biology & Urban \\
\hline
\end{tabular}

\section{References Reviewed Articles (S1)}

Albuquerque JRA, Oliveira B (2014) Interações entre humanos e Callithrix jacchus (Linnaeus, 1758) no Parque Estadual Dois Irmãos, Recife-PE, Brasil. In: A Primatologia no Brasil, pp.110-123

Alves RRN, Souto WMS, Barboza RRD, Bezerra DMM (2012) Primates in Traditional Folk Medicine: 
World Overview. In: Animals in Traditional Folk Medicine, pp. 135-170

Alves RRN, Barboza RRD, Souto WMS (2017) Primates in Traditional Folk Medicine. Int. Encycl. Primatology doi: 10.1002/9781119179313.wbprim0168.

Araújo AJB, Liesenfeld MVA (2018) Ocorrência de Primatas Não-Humanos no Ambiente Urbano de Cruzeiro do Sul, Acre, Brasil. Biodiversidade Brasileira 7:113-127

Batista WP, Neto EMC, Spagnoletti N (2017) Relação entre humanos e primatas (Sapajus sp.) às margens do Rio São Francisco, Nordeste, Brasil. Ethnoscientia 2.

Brasileiro L, Almeida LE, Saito TH (2011) Percepção dos visitantes do Parque Nacional de Brasília sobre sua interação com Cebus libidinosus: subsídios para uma prática de educação ambiental e de conduta consciente de visitantes de unidade de conservação da natureza. Rev. eletrônica Mestr. Educ. Ambient. 26:1517-1256.

Buss G, Romanowski HP, Becker FG (2015) O bugio que habita a mata e a mente dos moradores de Itapuã - Uma análise de percepção ambiental no entorno do Parque Estadual de Itapuã, Viamão, RS. Revista Biociências 21:14-28.

Chaves ÓM, Bicca-Marques JC (2017) Crop Feeding by Brown Howlers (Alouatta guariba clamitans) in Forest Fragments: The Conservation Value of Cultivated Species. Int. J. Primatol. 38:263-281

Cormier L, Cormier L (2006) A Preliminary Review of Neotropical Primates in the Subsistence and Symbolism of Indigenous Lowland South American Peoples. Ecol. Environ. Anthropol. 2:14-32.

Cornier LA (2003) Chapter 4: Monkey as food, monkey as child: Guajá symbolic cannibalism. In: Kinship with Monkeys: The Guaja Foragers of Eastern Amazonia. Columbia University Press.

Almeida AS, Voltolini JC (2018) Percepção ambiental dos moradores do entorno da Mata do Bugio sobre bugios-ruivos Alouatta guariba clamitans Cabrera 1940, em Taubaté, SP. Rev. Biociências $23: 54-64$.

Freitas CH, Setz EZ, Araújo AR, Gobbi N (2008) Agricultural crops in the diet of bearded capuchin monkeys, Cebus libidinosus Spix (Primates: Cebidae), in forest fragments in southeast Brazil. Rev. Bras. Zool. 25:32-39.

Filho RF, Pinto T, Bezerra BM (2018) Using local ecological knowledge to access the distribution of the Endangered Caatinga howler monkey (Alouatta ululata). Ethnobiology and Conservation 7:1-6. doi: 10.15451/ec2018-08-7.10-1-22

Garcia U (2018) Macacos também choram, ou esboço para um conceito ameríndio de espécie. Revista do Instituto de Estudos Brasileiros 69:179-204.

Gordo M, Callei FO, Vasconcelos SA, Leite JJ, Ferrari SD (2013) The Challenges of Survival in a Concrete Jungle: Conservation of the Pied Tamarin (Saguinus bicolor) in the Urban Landscape of Manaus, Brazil. In: Primates in Fragments. Springer, New York, NY, pp. 357-370.

Jerusalinsky L, Teixeira FZ, Lokischin LX, Alonso A, Jardim MMDA, Cabral JNH, Buss G (2010) Primatology in southern Brazil: a transdisciplinary approach to the conservation of the brown-howler-monkey Alouatta guariba clamitans (Primates, Atelidae). Iheringia. Série Zoologia 100:403-412.

Leite GC, Duarte MH, Young RJ (2011) Human-marmoset interactions in a city park. Applied Animal Behavior. Sci. 132:187-192.

Nunes AV, Silva Vilela J, Saldo AP, Santos BA, Fischer E (2017) Conhecimento e uso de primatas por uma população extrativista no Vale do Juruá, Amazônia. Biodiversidade Brasileira 7:123-132.

Paim FP, Aquino SP, Valsecchi J (2012) Does Ecotourism Activity Affect Primates In Mamirauá Reserve? A Atividade De Ecoturismo Na Reserva Mamirauá Afeta Os Primatas? Uakari 2:43-50.

Peres C (1991) Humboldt's woolly monkeys decimated by hunting in Amazonia. Oryx 25:89-95.

Peres CA (1997) Effects of Habitat Quality and Huntint Pressure on Arboreal Folivore Densities in Neotropical Forests: A case of Howler Monkeys (Alouatta spp.). Folia Primatologica 68:199-222. 
Rapchan ES (2016) Casas, Espaços Públicos E Parques - O Caso Entre Os Macacos- Prego E a Cidade Em Maringá. Iluminuras 4:350-371.

Rapchan ES, Neves W (2016) Famílias Híbridas: Camponeses, Primatólogos E Macacos-Prego No Cerrado Piauiense. Teoria e Cultura 5968:107-117.

Rocha LC, Fortes VB (2015) Perceptions and attitudes of rural residents towards capuchin monkeys, in the area of influence of the Dona Francisca Hydroelectric power plant, South Brazil. Ambiente e Sociedade 18.

Rodrigues NN, Martinez RA (2014) Wildlife in our backyard: interactions between Wied's marmoset Callithrix kuhlii (Primates: Callithrichidae) and residents of Ilhéus, Bahia, Brazil. Wildlife Biology 20:91-96.

Sabbatini G, Stamatti M, Tavares MCH, Giuliani MV, Visalberghi E (2006) Interactions between humans and capuchin monkeys (Cebus libidinosus) in the Parque Nacional de Brasília, Brazil. Applied Animal Behavior. Sci. 97:272-283.

Sabbatini G Stamatti M, Tavares MCH, Visalberghi E (2008) Behavioral flexibility of a group of bearded capuchin monkeys (Cebus libidinosus) in the National Park of Brasília (Brazil): consequences of cohabitation with visitors. Brazilian Journal of Biology 68:685-693.

Saito CH, Brasileiro L, Almeida LED, Tavares MCH (2010) Conflitos entre macacos-prego e visitantes no Parque Nacional de Brasília: possíveis soluções. Sociedade \& Natureza 22.

Santos LS, Pereira SH, Gordo M (2017) Simpatria entre populações humanas e de sauim-de-coleira (Saguinus bicolor) em fragmentos florestais de Manaus, Amazonas. Neotropical Primates 23.

Silveira FLA, Silva MHPD (2017) Dos galhos às grades: cotidiano e relações interespécies no "Bosque". Reflexões sobre as interações face a face entre humanos e macacos-de-cheiro (Saimiri sciureus sciureus) na cidade (Belém-PA). Horizontes Antropológicos 23:99-127.

Spagnoletti N, Cardoso TCM, Fragaszy D, Izar P (2017) Coexistence Between Humans and Capuchins (Sapajus libidinosus): Comparing Observational Data with Farmers' Perceptions of Crop Losses. International Journal of Primatology 38:243-262.

Suzin A et al (2017) The Relationship Between Humans and Capuchins (Sapajus sp.) in an Urban Green Area in Brazil. International Journal of Primatology doi:10.1007/s10764-017-9996-3

Suzin A, Back JP, Garey MV, Aguiar LM (2017) The Relationship Between Humans and Capuchins (Sapajus sp.) in an Urban Green Area in Brazil. International Journal of Primatology 38:1058-1071.

Teixeira B, Hirsch A, Goulart VD, Passos L, Teixeira CP, James P, Young R (2015) Good neighbours: Distribution of black-tufted marmoset (Callithrix penicillata) in an urban environment. Wildlife Research 42:579-589.

Torres EUJ, Valença-Montenegro MM, Castro CSS (2016) Local Ecological Knowlede about Endangered Primates in a Rural Community in Paraíba, Brazil. Folia Primatologica 87:262-277.

Waller MT (2016) Ethnoprimatology: Primate conservation in the 21st century. doi: 10.1007/978-3319-30469-4. 


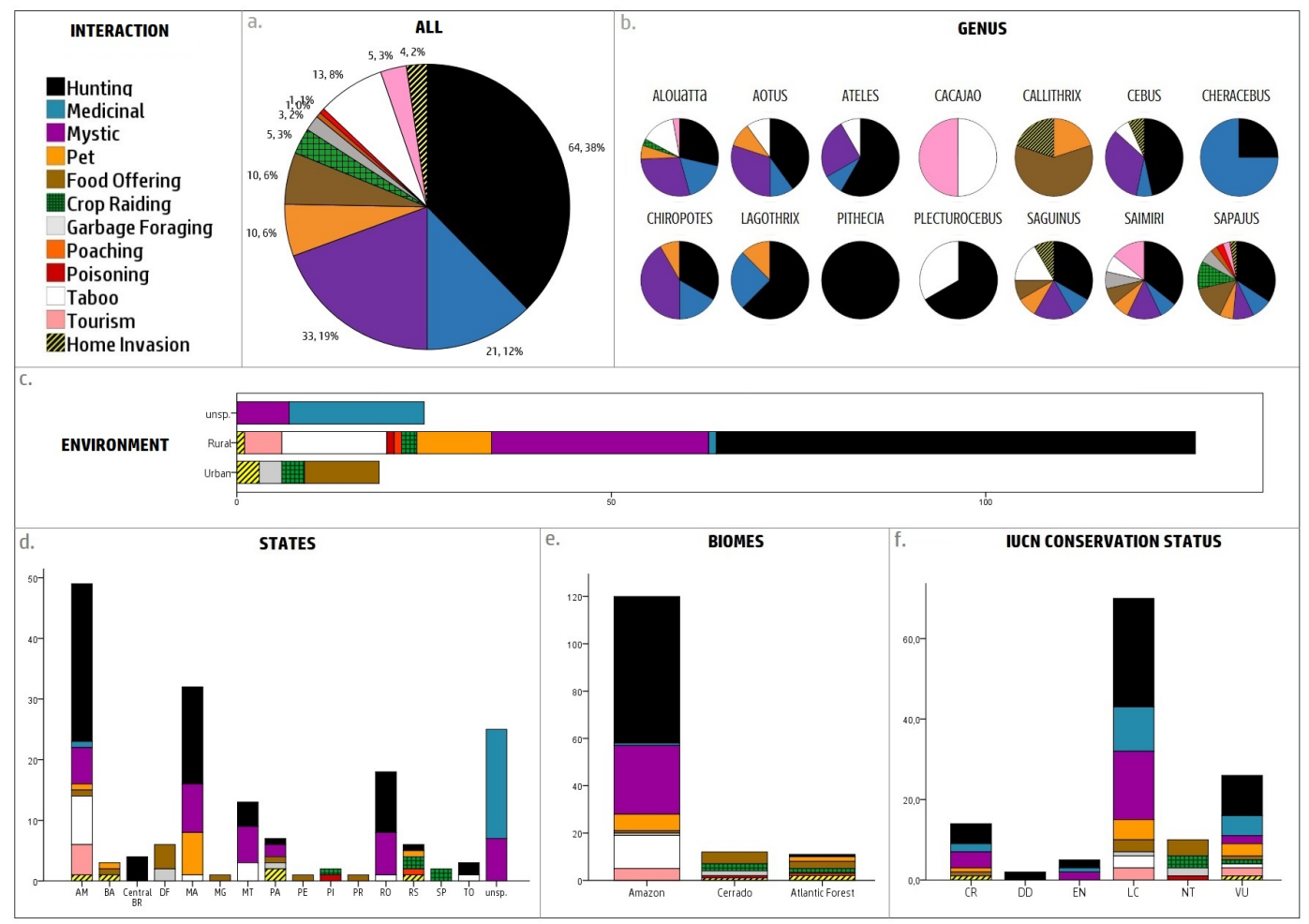

Add File 3. Quantitative. (a) Total percentage found for each type of interaction. (b) Total percentage found for each type of interaction per Genus of Primate. (c) Interactions by type of Environment/Human settlement. (d) Interactions distribution by States of Brazil. (e) Interactions distribution by Biomes of Brazil. (f) Interactions distribution by IUCN Conservation Status of Primates. 
Add File 4. Review Data. Legend (C.V. = Conservation Status, P.T. = Population Trend $(\mathrm{D}=\mathrm{Decreasing}, \mathrm{U}=\mathrm{Unknown}, \mathrm{S}=\mathrm{Stable}), \mathrm{IC}=\mathrm{Indigenous}$ Community, State $=\mathrm{S}(\mathrm{CB}=$ Central Brazil, $\mathrm{U}=$ Unspecifie $)$, Biome $=\mathrm{B}(\mathrm{A}=$ Amazônia, $\mathrm{C}=\mathrm{Cerrado}, \mathrm{MA}=\mathrm{Mata}$ Atlântica, $\mathrm{P}=\mathrm{Pampa}, \mathrm{PA}=\mathrm{Paulo}$ Afonso, $\mathrm{U}=$ Unspecified), ENVIR. = Environment)

\begin{tabular}{|c|c|c|c|c|c|c|c|c|c|c|}
\hline FAMILY & SPECIES & CS & P.T. & $\begin{array}{l}\text { INTERACTION/ } \\
\text { RELATIONSHIP }\end{array}$ & $\mathbf{S}$ & B & $\begin{array}{c}\text { CITY/IC/ } \\
\text { MUNICIPALITY }\end{array}$ & REFERENCE & YEAR & ENVIR. \\
\hline Atelidae & Alouatta belzebul & VU & $\mathrm{D}$ & Hunting & MA & $\mathrm{A}$ & Guajá & Cornier & 2006 & Rural \\
\hline Atelidae & Alouatta belzebul & VU & $\mathrm{D}$ & $\begin{array}{l}\text { Rural Proximity } \\
\text { Mystic/Folklore/ }\end{array}$ & MA & $\mathrm{A}$ & Guajá & Cornier & 2006 & Rural \\
\hline Atelidae & Alouatta belzebul & VU & $\mathrm{D}$ & $\begin{array}{l}\text { Magic/Religion/ } \\
\text { Ritual }\end{array}$ & MA & $\mathrm{A}$ & Guajá & Cornier & 2006 & Rural \\
\hline Atelidae & Alouatta belzebul & VU & $\mathrm{D}$ & $\begin{array}{l}\text { Pet } \\
\text { Mystic/Folklore/ }\end{array}$ & MA & $\mathrm{A}$ & Guajá & Garcia & 2018 & Rural \\
\hline Atelidae & Alouatta belzebul & VU & $\mathrm{D}$ & $\begin{array}{l}\text { Magic/Religion/ } \\
\text { Ritual }\end{array}$ & MA & $\mathrm{A}$ & Guajá & Garcia & 2018 & Rural \\
\hline Atelidae & Alouatta belzebul & VU & $\mathrm{D}$ & Hunting & MA & $\mathrm{A}$ & Guajá & Garcia & 2018 & Rural \\
\hline Atelidae & Alouatta belzebul & VU & $\mathrm{D}$ & Pet & MA & $\mathrm{A}$ & Guajá & Cornier & 2003 & Rural \\
\hline Atelidae & Alouatta belzebul & VU & $\mathrm{D}$ & Rural Proximity & MA & $\mathrm{A}$ & Guajá & Cornier & 2003 & Rural \\
\hline Atelidae & Alouatta belzebul & VU & $\mathrm{D}$ & Hunting & MA & $\mathrm{A}$ & Guajá & Cornier & 2003 & Rural \\
\hline Atelidae & Alouatta belzebul & VU & $\mathrm{D}$ & Rural Proximity & $\mathrm{PB}$ & MA & Lerolândia & Torres & 2016 & Rural \\
\hline Atelidae & Alouatta belzebul & VU & $\mathrm{D}$ & Medicinal & $\mathrm{U}$ & $\mathrm{U}$ & $\mathrm{U}$ & Alves et al & 2012 & $\mathrm{U}$ \\
\hline Atelidae & Alouatta guariba & VU & $\mathrm{D}$ & Medicinal & $\mathrm{U}$ & $\mathrm{U}$ & $\mathrm{U}$ & Alves et al & 2012 & $\mathrm{U}$ \\
\hline Atelidae & Alouatta guariba & VU & $\mathrm{D}$ & Medicinal & $\mathrm{U}$ & $\mathrm{U}$ & $\mathrm{U}$ & Alves \& Barboza & 2017 & $\mathrm{U}$ \\
\hline Atelidae & Alouatta guariba clamitans & VU & $\mathrm{D}$ & Urban Proximity & SP & MA & Taubaté & de Almeida e Silva & 2017 & Urban \\
\hline Atelidae & Alouatta guariba clamitans & VU & $\mathrm{D}$ & Urban Proximity & $\mathrm{RS}$ & $\mathrm{P}$ & $\begin{array}{l}\text { Parque Estad- } \\
\text { ual de Itapuã }\end{array}$ & Buss & 2015 & Urban \\
\hline Atelidae & Alouatta guariba clamitans & VU & $\mathrm{D}$ & Crop raiding & $\mathrm{RS}$ & MA & Porto Alegre & Chaves & 2016 & Urban \\
\hline Atelidae & Alouatta guariba clamitans & VU & $\mathrm{D}$ & Urban Proximity & $\mathrm{RS}$ & MA & Porto Alegre & Chaves & 2016 & Urban \\
\hline Atelidae & Alouatta guariba clamitans & VU & $\mathrm{D}$ & Urban Proximity & $\mathrm{RS}$ & MA & Porto Alegre & Jerusalinsky et al & 2010 & Urban \\
\hline Atelidae & Alouatta juara & $\mathrm{LC}$ & $\mathrm{D}$ & Tourism & $\mathrm{AM}$ & $\mathrm{A}$ & $\begin{array}{l}\text { Uakari Lodge } \\
\text { (Mamirauá) }\end{array}$ & Paim et al & 2012 & Rural \\
\hline Atelidae & Alouatta juara & $\mathrm{LC}$ & $\mathrm{D}$ & Hunting & $\mathrm{AM}$ & $\mathrm{A}$ & Vale do Juruá & Nunes et al & 2017 & Rural \\
\hline Atelidae & Alouatta juara & $\mathrm{LC}$ & $\mathrm{D}$ & Rural Proximity & $\mathrm{AM}$ & $\mathrm{A}$ & Vale do Juruá & Nunes et al & 2017 & Rural \\
\hline Atelidae & Alouatta juara & $\mathrm{LC}$ & $\mathrm{D}$ & Rural Proximity & $\mathrm{AM}$ & $\mathrm{A}$ & $\begin{array}{l}\text { Uakari Lodge } \\
\text { (Mamirauá) }\end{array}$ & Paim et al & 2012 & Rural \\
\hline Atelidae & Alouatta nigerrima & $\mathrm{LC}$ & $\mathrm{D}$ & Medicinal & $\mathrm{U}$ & $\mathrm{U}$ & $\mathrm{U}$ & Alves et al & 2012 & $\mathrm{U}$ \\
\hline Atelidae & Alouatta seniculus & $\mathrm{LC}$ & $\mathrm{D}$ & Hunting & $\mathrm{AM}$ & $\mathrm{A}$ & Matis & Cornier & 2006 & Rural \\
\hline Atelidae & Alouatta seniculus & $\mathrm{LC}$ & $\mathrm{D}$ & Rural Proximity & $\mathrm{AM}$ & $\mathrm{A}$ & Matis & Cornier & 2006 & Rural \\
\hline Atelidae & Alouatta seniculus & $\mathrm{LC}$ & $\mathrm{D}$ & Hunting & $\mathrm{CB}$ & $\mathrm{A}$ & $\begin{array}{l}\text { Waimiri } \\
\text { Atroari }\end{array}$ & Cornier & 2006 & Rural \\
\hline
\end{tabular}




\begin{tabular}{|c|c|}
\hline Atelidae & Alouatta seniculus \\
\hline Atelidae & Alouatta seniculus \\
\hline Atelidae & Alouatta seniculus \\
\hline Atelidae & Alouatta seniculus \\
\hline Atelidae & Alouatta seniculus \\
\hline Atelidae & Alouatta seniculus \\
\hline Atelidae & Alouatta seniculus \\
\hline Atelidae & Alouatta seniculus \\
\hline Atelidae & Alouatta sp. \\
\hline Atelidae & Alouatta sp. \\
\hline Atelidae & Alouatta sp. \\
\hline Atelidae & Alouatta sp. \\
\hline Atelidae & Alouatta sp. \\
\hline Atelidae & Alouatta sp. \\
\hline Atelidae & Alouatta sp. \\
\hline Atelidae & Alouatta sp. \\
\hline Atelidae & Alouatta sp. \\
\hline Atelidae & Alouatta sp. \\
\hline Atelidae & Alouatta sp. \\
\hline Atelidae & Alouatta sp. \\
\hline Atelidae & Alouatta sp. \\
\hline Atelidae & Alouatta sp. \\
\hline Atelidae & Alouatta sp. \\
\hline Atelidae & Alouatta sp. \\
\hline Atelidae & Alouatta sp. \\
\hline Atelidae & Alouatta sp. \\
\hline Atelidae & Alouatta sp. \\
\hline Atelidae & Alouatta sp. \\
\hline Atelidae & Alouatta sp. \\
\hline Atelidae & Alouatta sp. \\
\hline
\end{tabular}

\begin{tabular}{|c|c|c|c|c|c|c|}
\hline $\mathrm{LC}$ & $\mathrm{D}$ & Rural Proximity & $\mathrm{CB}$ & $\mathrm{A}$ & $\begin{array}{l}\text { Waimiri } \\
\text { Atroari }\end{array}$ & Cornier \\
\hline $\mathrm{LC}$ & $\mathrm{D}$ & Hunting & $\mathrm{RO}$ & $\mathrm{A}$ & Wapishana & Cornier \\
\hline $\mathrm{LC}$ & $\mathrm{D}$ & $\begin{array}{l}\text { Rural Proximity } \\
\text { Mystic/Folklore/ }\end{array}$ & $\mathrm{RO}$ & $\mathrm{A}$ & Wapishana & Cornier \\
\hline $\mathrm{LC}$ & $\mathrm{D}$ & $\begin{array}{l}\text { Magic/Religion/ } \\
\text { Ritual }\end{array}$ & $\mathrm{AM}$ & $\mathrm{A}$ & Yanomami & Cornier \\
\hline $\mathrm{LC}$ & $\mathrm{D}$ & $\begin{array}{l}\text { Rural Proximity } \\
\text { Mystic/Folklore/ }\end{array}$ & $\mathrm{AM}$ & $\mathrm{A}$ & Yanomami & Cornier \\
\hline LC & D & $\begin{array}{l}\text { Magic/Religion/ } \\
\text { Ritual }\end{array}$ & $\mathrm{RO}$ & A & Yanomami & Cornier \\
\hline $\mathrm{LC}$ & $\mathrm{D}$ & Medicinal & $\mathrm{U}$ & $\mathrm{U}$ & $\mathrm{U}$ & Alves et al \\
\hline \multirow[t]{23}{*}{$\mathrm{LC}$} & $\mathrm{D}$ & Medicinal & $\mathrm{U}$ & $\mathrm{U}$ & $\mathrm{U}$ & Alves \& Barboza \\
\hline & & Hunting & TO & $\mathrm{A}$ & Tapirapé & Cornier \\
\hline & & Rural Proximity & TO & $\mathrm{A}$ & Tapirapé & Cornier \\
\hline & & Hunting & MT & $\mathrm{A}$ & Tapirapé & Cornier \\
\hline & & Rural Proximity & $\mathrm{MT}$ & $\mathrm{A}$ & Tapirapé & Cornier \\
\hline & & Taboo/Eating avoidance & $\mathrm{AM}$ & $\mathrm{A}$ & Desana & Cornier \\
\hline & & Rural Proximity & $\mathrm{AM}$ & $\mathrm{A}$ & Desana & Cornier \\
\hline & & Taboo/Eating avoidance & $\mathrm{AM}$ & $\mathrm{A}$ & Matses & Cornier \\
\hline & & Rural Proximity & $\mathrm{AM}$ & $\mathrm{A}$ & Matses & Cornier \\
\hline & & Taboo/Eating avoidance & MT & $\mathrm{A}$ & Suyá & Cornier \\
\hline & & Rural Proximity & $\mathrm{MT}$ & $\mathrm{A}$ & Suyá & Cornier \\
\hline & & Taboo/Eating avoidance & $\mathrm{TO}$ & $\mathrm{A}$ & Tapirapé & Cornier \\
\hline & & Rural Proximity & TO & $\mathrm{A}$ & Tapirapé & Cornier \\
\hline & & Taboo/Eating avoidance & MT & $\mathrm{A}$ & Tapirapé & Cornier \\
\hline & & $\begin{array}{l}\text { Rural Proximity } \\
\text { Mystic/Folklore/ }\end{array}$ & MT & $\mathrm{A}$ & Tapirapé & Cornier \\
\hline & & $\begin{array}{l}\text { Magic/Religion/ } \\
\text { Ritual }\end{array}$ & MT & $\mathrm{A}$ & $\begin{array}{l}\text { Juruna } \\
\text { (Yudjá) }\end{array}$ & Cornier \\
\hline & & Rural Proximity & MT & $\mathrm{A}$ & $\begin{array}{l}\text { Juruna } \\
\text { (Yudjá) }\end{array}$ & Cornier \\
\hline & & $\begin{array}{l}\text { Mystic/Folklore/ } \\
\text { Magic/Religion/ } \\
\text { Ritual }\end{array}$ & $\mathrm{PA}$ & $\mathrm{A}$ & Munducurú & Cornier \\
\hline & & $\begin{array}{l}\text { Rural Proximity } \\
\text { Mystic/Folklore/ }\end{array}$ & $\mathrm{PA}$ & $\mathrm{A}$ & Munducurú & Cornier \\
\hline & & $\begin{array}{l}\text { Magic/Religion/ } \\
\text { Ritual }\end{array}$ & $\mathrm{AM}$ & $\mathrm{A}$ & Munducurú & Cornier \\
\hline & & $\begin{array}{l}\text { Rural Proximity } \\
\text { Mvstic/Folklore/ }\end{array}$ & $\mathrm{AM}$ & $\mathrm{A}$ & Munducurú & Cornier \\
\hline & & $\begin{array}{l}\text { Magic/Religion/ } \\
\text { Ritual }\end{array}$ & MT & $\mathrm{A}$ & Munducurú & Cornier \\
\hline & & Rural Proximity & $\mathrm{MT}$ & $\mathrm{A}$ & Munducurú & Cornier \\
\hline
\end{tabular}

\begin{tabular}{|c|c|}
\hline 2006 & Rural \\
\hline 2006 & Rural \\
\hline 2006 & Rural \\
\hline 2006 & Rural \\
\hline 2006 & Rural \\
\hline 2006 & Rural \\
\hline 2012 & $\mathrm{U}$ \\
\hline 2017 & $\mathrm{U}$ \\
\hline 2006 & Rural \\
\hline 2006 & Rural \\
\hline 2006 & Rural \\
\hline 2006 & Rural \\
\hline 2006 & Rural \\
\hline 2006 & Rural \\
\hline 2006 & Rural \\
\hline 2006 & Rural \\
\hline 2006 & Rural \\
\hline 2006 & Rural \\
\hline 2006 & Rural \\
\hline 2006 & Rural \\
\hline 2006 & Rural \\
\hline 2006 & Rural \\
\hline 2006 & Rural \\
\hline 2006 & Rural \\
\hline 2006 & Rural \\
\hline 2006 & Rural \\
\hline 2006 & Rural \\
\hline 2006 & Rural \\
\hline 2006 & Rural \\
\hline 2006 & Rural \\
\hline
\end{tabular}




\begin{tabular}{|c|c|c|c|c|c|c|c|c|c|c|}
\hline Atelidae & Alouatta sp. & & & $\begin{array}{l}\text { Mystic/Folklore/ } \\
\text { Magic/Religion/ } \\
\text { Ritual }\end{array}$ & $\mathrm{MT}$ & $\mathrm{A}$ & Xikrin & Cornier & 2006 & Rural \\
\hline Atelidae & Alouatta sp. & & & $\begin{array}{l}\text { Rural Proximity } \\
\text { Mystic/Folklore/ }\end{array}$ & $\mathrm{MT}$ & $\mathrm{A}$ & Xikrin & Cornier & 2006 & Rural \\
\hline Atelidae & Alouatta sp. & & & $\begin{array}{l}\text { Magic/Religion/ } \\
\text { Ritual }\end{array}$ & $\mathrm{PA}$ & $\mathrm{A}$ & Xikrin & Cornier & 2006 & Rural \\
\hline Atelidae & Alouatta sp. & & & Rural Proximity & $\mathrm{PA}$ & $\mathrm{A}$ & Xikrin & Cornier & 2006 & Rural \\
\hline Atelidae & Alouatta sp. & & & Hunting & $\mathrm{AM}$ & $\mathrm{A}$ & $\begin{array}{l}\text { Central Ama- } \\
\text { zonia }\end{array}$ & Peres & 1997 & Rural \\
\hline Atelidae & Alouatta ululata & EN & $\mathrm{D}$ & Rural Proximity & PI & $\mathrm{C}$ & $\begin{array}{l}\text { Castelo do Pi- } \\
\text { aui e Valença } \\
\text { do Piauí }\end{array}$ & Filho et al & 2018 & Rural \\
\hline Atelidae & Alouatta ululata & EN & $\mathrm{D}$ & Rural Proximity & $\mathrm{CE}$ & MA & $\begin{array}{l}\text { Serra da Ibiapa } \\
\text { Protection Are } \\
\text { Environmental }\end{array}$ & $\begin{array}{l}\text { ironmental } \\
\text { a da Meruoca } \\
\text { ion area }\end{array}$ & & \\
\hline Aotidae & Aotus azarae & $\mathrm{LC}$ & $\mathrm{D}$ & Medicinal & $\mathrm{U}$ & $\mathrm{U}$ & $\mathrm{U}$ & Alves \& Barboza & 2017 & $\mathrm{U}$ \\
\hline Atelidae & Ateles belzebuth & $\mathrm{EN}$ & $\mathrm{D}$ & Medicinal & $\mathrm{U}$ & $\mathrm{U}$ & $\mathrm{U}$ & Alves \& Barboza & 2017 & $\mathrm{U}$ \\
\hline Aotidae & Aotus azarae & $\mathrm{LC}$ & $\mathrm{D}$ & Hunting & MA & $\mathrm{A}$ & Guajá & Cornier & 2006 & Rural \\
\hline Aotidae & Aotus azarae & $\mathrm{LC}$ & $\mathrm{D}$ & $\begin{array}{l}\text { Rural Proximity } \\
\text { Mystic/Folklore/ }\end{array}$ & MA & $\mathrm{A}$ & Guajá & Cornier & 2006 & Rural \\
\hline Aotidae & Aotus azarae & $\mathrm{LC}$ & $\mathrm{D}$ & $\begin{array}{l}\text { Magic/Religion/ } \\
\text { Ritual }\end{array}$ & MA & $\mathrm{A}$ & Guajá & Cornier & 2006 & Rural \\
\hline Aotidae & Aotus azarae & $\mathrm{LC}$ & $\mathrm{D}$ & Pet & MA & $\mathrm{A}$ & Guajá & Cornier & 2003 & Rural \\
\hline Aotidae & Aotus azarae & $\mathrm{LC}$ & $\mathrm{D}$ & Rural Proximity & MA & $\mathrm{A}$ & Guajá & Cornier & 2003 & Rural \\
\hline Aotidae & Aotus azarae & $\mathrm{LC}$ & $\mathrm{D}$ & $\begin{array}{l}\text { Hunting } \\
\text { Mystic/Folklore/ }\end{array}$ & MA & $\mathrm{A}$ & Guajá & Cornier & 2003 & Rural \\
\hline Aotidae & Aotus azarae & $\mathrm{LC}$ & $\mathrm{D}$ & $\begin{array}{l}\text { Magic/Religion/ } \\
\text { Ritual }\end{array}$ & $\mathrm{U}$ & $\mathrm{U}$ & $\mathrm{U}$ & Alves et al & 2016 & $\mathrm{U}$ \\
\hline Aotidae & Aotus nigriceps & $\mathrm{LC}$ & $\mathrm{U}$ & Urban Proximity & $\mathrm{AC}$ & $\mathrm{A}$ & $\begin{array}{l}\text { Cruzeiro do } \\
\text { Sul }\end{array}$ & Araújo \& Liesenfeld & 2017 & Urban \\
\hline Aotidae & Aotus nigriceps & $\mathrm{LC}$ & $\mathrm{U}$ & Hunting & $\mathrm{AM}$ & $\mathrm{A}$ & Vale do Juruá & Nunes et al & 2017 & Rural \\
\hline Aotidae & Aotus nigriceps & $\mathrm{LC}$ & $\mathrm{U}$ & Rural Proximity & $\mathrm{AM}$ & $\mathrm{A}$ & Vale do Juruá & Nunes et al & 2017 & Rural \\
\hline Aotidae & Aotus sp. & & & Hunting & $\mathrm{AM}$ & $\mathrm{A}$ & Matis & Cornier & 2006 & Rural \\
\hline Aotidae & Aotus sp. & & & Rural Proximity & $\mathrm{AM}$ & $\mathrm{A}$ & Matis & Cornier & 2006 & Rural \\
\hline Aotidae & Aotus sp. & & & $\begin{array}{l}\text { Taboo/Eating avoidance } \\
\text { Mystic/Folklore/ }\end{array}$ & $\mathrm{AM}$ & $\mathrm{A}$ & Desana & Cornier & 2006 & Rural \\
\hline Aotidae & Aotus sp. & & & $\begin{array}{l}\text { Magic/Religion/ } \\
\text { Ritual }\end{array}$ & MT & $\mathrm{A}$ & $\begin{array}{l}\text { Juruna } \\
\text { (Yudjá) }\end{array}$ & Cornier & 2006 & Rural \\
\hline Aotidae & Aotus sp. & & & Rural proximity & $\mathrm{MT}$ & $\mathrm{A}$ & $\begin{array}{l}\text { Juruna } \\
\text { (Yudjá) }\end{array}$ & Cornier & 2006 & Rural \\
\hline Atelidae & Ateles belzebuth & EN & $\mathrm{D}$ & $\begin{array}{l}\text { Mystic/Folklore/ } \\
\text { Magic/Religion/ } \\
\text { Ritual }\end{array}$ & $\mathrm{AM}$ & $\mathrm{A}$ & Yanomami & Cornier & 2006 & Rural \\
\hline
\end{tabular}




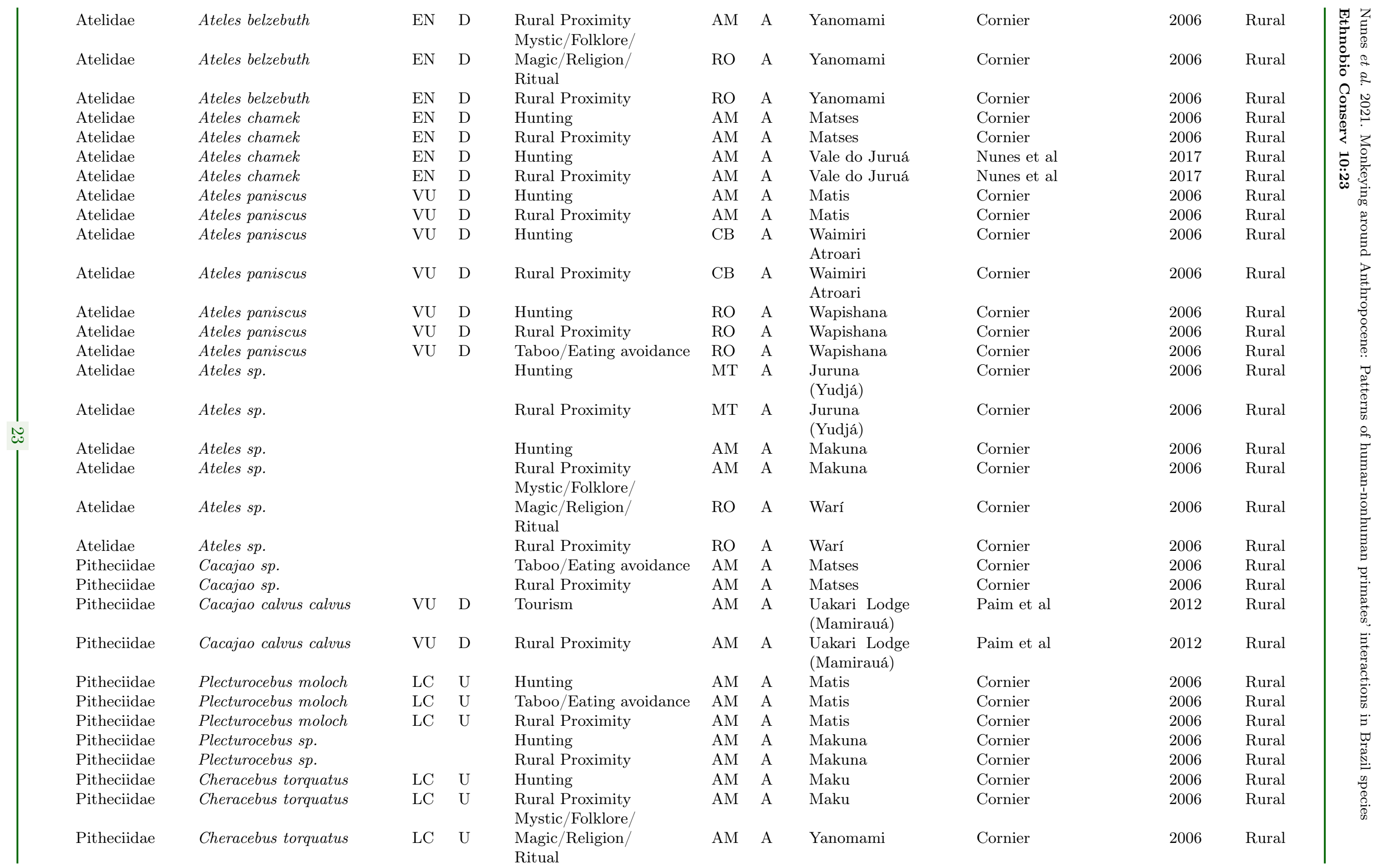




\begin{tabular}{|c|c|c|c|c|}
\hline Pitheciidae & Cheracebus torquatus & $\mathrm{LC}$ & $\mathrm{U}$ & $\begin{array}{l}\text { Rural Proximity } \\
\text { Mystic/Folklore/ }\end{array}$ \\
\hline Pitheciidae & Cheracebus torquatus & $\mathrm{LC}$ & $\mathrm{U}$ & $\begin{array}{l}\text { Magic/Religion/ } \\
\text { Ritual }\end{array}$ \\
\hline Pitheciidae & Cheracebus torquatus & $\mathrm{LC}$ & $\mathrm{U}$ & $\begin{array}{l}\text { Rural Proximity } \\
\text { Mystic/Folklore/ }\end{array}$ \\
\hline Pitheciidae & Cheracebus torquatus & $\mathrm{LC}$ & $\mathrm{U}$ & $\begin{array}{l}\text { Magic/Religion/ } \\
\text { Ritual }\end{array}$ \\
\hline Pitheciidae & Cheracebus torquatus & $\mathrm{LC}$ & $\mathrm{U}$ & Medicinal \\
\hline Calliitrichidae & Callithrix jacchus & $\mathrm{LC}$ & $\mathrm{D}$ & Urban Proximity \\
\hline Calliitrichidae & Callithrix jacchus & $\mathrm{LC}$ & $\mathrm{D}$ & Food offering \\
\hline Calliitrichidae & Callithrix jacchus & $\mathrm{LC}$ & $\mathrm{D}$ & Rural Proximity \\
\hline Calliitrichidae & Callithrix jacchus & $\mathrm{LC}$ & $\mathrm{D}$ & Pet \\
\hline Calliitrichidae & Callithrix penicillata & $\mathrm{LC}$ & $\mathrm{D}$ & Urban Proximity \\
\hline Calliitrichidae & Callithrix penicillata & $\mathrm{LC}$ & $\mathrm{D}$ & Urban Proximity \\
\hline Calliitrichidae & Callithrix penicillata & $\mathrm{LC}$ & $\mathrm{D}$ & Food offering \\
\hline Calliitrichidae & Callithrix kuhlii & VU & $\mathrm{D}$ & Urban Proximity \\
\hline Calliitrichidae & Callithrix kuhlii & VU & $\mathrm{D}$ & Home Invasion \\
\hline Calliitrichidae & Callithrix kuhlii & VU & $\mathrm{D}$ & Food offering \\
\hline Calliitrichidae & Cebuella niveiventris & $\mathrm{LC}$ & $\mathrm{S}$ & Urban Proximity \\
\hline Cebidae & Cebus albifrons & $\mathrm{LC}$ & $\mathrm{D}$ & $\begin{array}{l}\text { Mystic/Folklore/ } \\
\text { Magic/Religion/ } \\
\text { Ritual }\end{array}$ \\
\hline Cebidae & Cebus albifrons & $\mathrm{LC}$ & $\mathrm{D}$ & $\begin{array}{l}\text { Rural Proximity } \\
\text { Mystic/Folklore/ }\end{array}$ \\
\hline Cebidae & Cebus albifrons & $\mathrm{LC}$ & $\mathrm{D}$ & $\begin{array}{l}\text { Magic/Religion/ } \\
\text { Ritual }\end{array}$ \\
\hline Cebidae & Cebus albifrons & $\mathrm{LC}$ & $\mathrm{D}$ & Rural Proximity \\
\hline Cebidae & Sapajus apella & $\mathrm{LC}$ & $\mathrm{D}$ & Hunting \\
\hline Cebidae & Sapajus apella & $\mathrm{LC}$ & $\mathrm{D}$ & Rural Proximity \\
\hline Cebidae & Sapajus apella & $\mathrm{LC}$ & $\mathrm{D}$ & Hunting \\
\hline Cebidae & Sapajus apella & $\mathrm{LC}$ & $\mathrm{D}$ & Rural Proximity \\
\hline Cebidae & Sapajus apella & $\mathrm{LC}$ & $\mathrm{D}$ & Hunting \\
\hline Cebidae & Sapajus apella & $\mathrm{LC}$ & $\mathrm{D}$ & Rural Proximity \\
\hline Cebidae & Sapajus apella & $\mathrm{LC}$ & $\mathrm{D}$ & Hunting \\
\hline
\end{tabular}

\begin{tabular}{|c|c|c|}
\hline $\mathrm{AM}$ & $\mathrm{A}$ & Yanoman \\
\hline RO & $\mathrm{A}$ & Yanoman \\
\hline RO & $\mathrm{A}$ & Yanoman \\
\hline $\mathrm{U}$ & $\mathrm{U}$ & $\mathrm{U}$ \\
\hline $\mathrm{U}$ & $\mathrm{U}$ & $\mathrm{U}$ \\
\hline $\mathrm{PE}$ & MA & $\begin{array}{l}\text { Parque Es } \\
\text { ual Dois } \\
\text { mãos }\end{array}$ \\
\hline $\mathrm{PE}$ & MA & $\begin{array}{l}\text { Parque Es } \\
\text { ual Dois } \\
\text { mãos }\end{array}$ \\
\hline $\mathrm{PB}$ & MA & Lerolândi \\
\hline PB & MA & Lerolândi \\
\hline MG & $\mathrm{C}$ & $\begin{array}{l}\text { Belo } \\
\text { zonte }\end{array}$ \\
\hline MG & $\mathrm{C}$ & $\begin{array}{l}\text { Belo } \\
\text { zonte }\end{array}$ \\
\hline MG & $\mathrm{C}$ & $\begin{array}{l}\text { Belo } \\
\text { zonte }\end{array}$ \\
\hline $\mathrm{BA}$ & MA & Ilhéus \\
\hline $\mathrm{BA}$ & MA & Ilhéus \\
\hline $\mathrm{BA}$ & MA & Ilhéus \\
\hline $\mathrm{AC}$ & $\mathrm{A}$ & $\begin{array}{l}\text { Cruzeiro } \\
\text { Sul }\end{array}$ \\
\hline $\mathrm{AM}$ & $\mathrm{A}$ & Yanoman \\
\hline $\mathrm{AM}$ & $\mathrm{A}$ & Yanoman \\
\hline RO & $\mathrm{A}$ & Yanoman \\
\hline RO & $\mathrm{A}$ & Yanoman \\
\hline $\mathrm{PA}$ & $\mathrm{A}$ & Arara \\
\hline $\mathrm{PA}$ & $\mathrm{A}$ & Arara \\
\hline MA & $\mathrm{A}$ & Guajá \\
\hline MA & $\mathrm{A}$ & Guajá \\
\hline $\mathrm{AM}$ & $\mathrm{A}$ & Matis \\
\hline $\mathrm{AM}$ & $\mathrm{A}$ & Matis \\
\hline $\mathrm{CB}$ & $\mathrm{A}$ & $\begin{array}{l}\text { Waimiri } \\
\text { Atroari }\end{array}$ \\
\hline
\end{tabular}

2006

Cornier

Alves et al

Alves \& Barboza

Albuquerque \& Oliveira

Albuquerque \& Oliveira 2014

Torres

Torres

Teixeira et al

Leite et al

Leite et al

Rodrigues \& Martinez

Rodrigues \& Martinez

Rodrigues \& Martinez

Araújo \& Liesenfeld

Cornier

Cornier

Cornier

Cornier

Cornier

Cornier

Cornier

Cornier

Cornier

Cornier

Cornier
2006

2016

2017

2016

2016

2015

2011

2011

2014

2014

2014

2017

2006

2006

2006

Rural

Rural

Rural

U

U

Urban

Urban

Rural

Rural

Urban

Urban

Urban

Urban

Urban

Urban

Urban

Rural

Rural

Rural

2006 Rural

2006 Rural

2006 Rural

2006 Rural

2006 Rural

2006 Rural

2006 Rural

2006 Rural 


\begin{tabular}{|c|c|c|c|c|c|c|c|c|c|c|}
\hline Cebidae & Sapajus apella & $\mathrm{LC}$ & $\mathrm{D}$ & Rural Proximity & $\mathrm{CB}$ & $\mathrm{A}$ & $\begin{array}{l}\text { Waimiri } \\
\text { Atroari }\end{array}$ & Cornier & 2006 & Rural \\
\hline Cebidae & Sapajus apella & $\mathrm{LC}$ & $\mathrm{D}$ & Hunting & $\mathrm{RO}$ & $\mathrm{A}$ & Wapishana & Cornier & 2006 & Rural \\
\hline Cebidae & Sapajus apella & $\mathrm{LC}$ & $\mathrm{D}$ & $\begin{array}{l}\text { Rural Proximity } \\
\text { Mystic/Folklore/ }\end{array}$ & $\mathrm{RO}$ & A & Wapishana & Cornier & 2006 & Rural \\
\hline Cebidae & Sapajus apella & $\mathrm{LC}$ & $\mathrm{D}$ & $\begin{array}{l}\text { Magic/Religion/ } \\
\text { Ritual }\end{array}$ & MA & A & Guajá & Cornier & 2006 & Rural \\
\hline Cebidae & Sapajus apella & $\mathrm{LC}$ & $\mathrm{D}$ & Pet & MA & A & Guajá & Cornier & 2003 & Rural \\
\hline Cebidae & Sapajus apella & $\mathrm{LC}$ & $\mathrm{D}$ & Rural Proximity & MA & $\mathrm{A}$ & Guajá & Cornier & 2003 & Rural \\
\hline Cebidae & Sapajus apella & $\mathrm{LC}$ & $\mathrm{D}$ & Hunting & MA & $\mathrm{A}$ & Guajá & Cornier & 2003 & Rural \\
\hline Cebidae & Sapajus apella & $\mathrm{LC}$ & $\mathrm{D}$ & Medicinal & $\mathrm{U}$ & $\mathrm{U}$ & $\mathrm{U}$ & Alves et al & 2012 & $\mathrm{U}$ \\
\hline Cebidae & Sapajus apella & $\mathrm{LC}$ & $\mathrm{D}$ & Medicinal & $\mathrm{U}$ & $\mathrm{U}$ & $\mathrm{U}$ & Alves \& Barboza & 2017 & $\mathrm{U}$ \\
\hline Cebidae & Cebus kaapori & $\mathrm{CR}$ & $\mathrm{D}$ & $\begin{array}{l}\text { Hunting } \\
\text { Mystic/Folklore/ }\end{array}$ & MA & $\mathrm{A}$ & Guajá & Cornier & 2006 & Rural \\
\hline Cebidae & Cebus kaapori & $\mathrm{CR}$ & $\mathrm{D}$ & $\begin{array}{l}\text { Magic/Religion/ } \\
\text { Ritual }\end{array}$ & MA & A & Guajá & Cornier & 2006 & Rural \\
\hline Cebidae & Cebus kaapori & $\mathrm{CR}$ & $\mathrm{D}$ & $\begin{array}{l}\text { Rural Proximity } \\
\text { Mystic/Folklore/ }\end{array}$ & MA & $\mathrm{A}$ & Guajá & Cornier & 2006 & Rural \\
\hline Cebidae & Cebus kaapori & $\mathrm{CR}$ & $\mathrm{D}$ & $\begin{array}{l}\text { Magic/Religion/ } \\
\text { Ritual }\end{array}$ & $\mathrm{U}$ & $\mathrm{U}$ & $\mathrm{U}$ & Alves et al & 2016 & $\mathrm{U}$ \\
\hline Cebidae & Sapajus libidinosus & NT & $\mathrm{D}$ & Crop raiding & SP & $\mathrm{C}$ & França & Freitas et al & 2008 & Urban \\
\hline Cebidae & Sapajus libidinosus & NT & $\mathrm{D}$ & Urban Proximity & SP & $\mathrm{C}$ & França & Freitas et al & 2008 & Urban \\
\hline Cebidae & Sapajus libidinosus & NT & $\mathrm{D}$ & Urban Proximity & $\mathrm{DF}$ & $\mathrm{C}$ & $\begin{array}{l}\text { National Park } \\
\text { of Brasilia }\end{array}$ & Brasileiro & 2011 & Urban \\
\hline Cebidae & Sapajus libidinosus & $\mathrm{NT}$ & $\mathrm{D}$ & Food offering & $\mathrm{DF}$ & $\mathrm{C}$ & $\begin{array}{l}\text { National Park } \\
\text { of Brasilia }\end{array}$ & Brasileiro & 2011 & Urban \\
\hline Cebidae & Cebus castaneus & $\mathrm{LC}$ & $\mathrm{U}$ & Hunting & $\mathrm{RO}$ & $\mathrm{A}$ & Wapishana & Cornier & 2006 & Rural \\
\hline Cebidae & Cebus castaneus & $\mathrm{LC}$ & $\mathrm{U}$ & Rural Proximity & $\mathrm{RO}$ & A & Wapishana & Cornier & 2006 & Rural \\
\hline Cebidae & Cebus sp. & & & Hunting & $\mathrm{MT}$ & $\mathrm{A}$ & $\begin{array}{l}\text { Juruna } \\
\text { (Yudjá) }\end{array}$ & Cornier & 2006 & Rural \\
\hline Cebidae & Cebus sp. & & & Rural Proximity & $\mathrm{MT}$ & $\mathrm{A}$ & $\begin{array}{l}\text { Juruna } \\
\text { (Yudjá) }\end{array}$ & Cornier & 2006 & Rural \\
\hline Cebidae & Sapajus sp. & & & Hunting & MA & $\mathrm{A}$ & Ka'apor & Cornier & 2006 & Rural \\
\hline Cebidae & Sapajus sp. & & & Rural Proximity & MA & A & Ka'apor & Cornier & 2006 & Rural \\
\hline Cebidae & Sapajus sp. & & & Hunting & TO & A & Tapirapé & Cornier & 2006 & Rural \\
\hline Cebidae & Sapajus sp. & & & Rural Proximity & TO & $\mathrm{A}$ & Tapirapé & Cornier & 2006 & Rural \\
\hline Cebidae & Sapajus sp. & & & Hunting & $\mathrm{MT}$ & $\mathrm{A}$ & Tapirapé & Cornier & 2006 & Rural \\
\hline Cebidae & Sapajus sp. & & & Rural Proximity & $\mathrm{MT}$ & $\mathrm{A}$ & Tapirapé & Cornier & 2006 & Rural \\
\hline Cebidae & Cebus sp. & & & Rural Proximity & $\mathrm{RO}$ & $\mathrm{A}$ & Yanomami & Cornier & 2006 & Rural \\
\hline Cebidae & Cebus sp. & & & Hunting & $\mathrm{RO}$ & A & Ye'kwana & Cornier & 2006 & Rural \\
\hline
\end{tabular}




\begin{tabular}{|c|c|c|c|c|}
\hline Cebidae & Cebus sp. & & & Rural Proximity \\
\hline Cebidae & Cebus sp. & & & Taboo/Eating avo \\
\hline Cebidae & Cebus sp. & & & $\begin{array}{l}\text { Rural Proximity } \\
\text { Mystic/Folklore/ }\end{array}$ \\
\hline Cebidae & Sapajus sp. & & & $\begin{array}{l}\text { Magic/Religion/ } \\
\text { Ritual }\end{array}$ \\
\hline Cebidae & Sapajus sp. & & & $\begin{array}{l}\text { Rural Proximity } \\
\text { Mystic/Folklore/ }\end{array}$ \\
\hline Cebidae & Sapajus sp. & & & $\begin{array}{l}\text { Magic/Religion/ } \\
\text { Ritual }\end{array}$ \\
\hline Cebidae & Sapajus sp. & & & $\begin{array}{l}\text { Rural Proximity } \\
\text { Mystic/Folklore/ }\end{array}$ \\
\hline Cebidae & Cebus sp. & & & $\begin{array}{l}\text { Magic/Religion/ } \\
\text { Ritual }\end{array}$ \\
\hline Cebidae & Cebus sp. & & & Rural Proximity \\
\hline Cebidae & Cebus sp. & & & Urban Proximity \\
\hline Cebidae & Cebus sp. & & & Home Invasion \\
\hline Cebidae & Cebus albifrons & $\mathrm{LC}$ & $\mathrm{D}$ & Hunting \\
\hline Cebidae & Sapajus flavius & $\mathrm{CR}$ & $\mathrm{D}$ & Poisoning \\
\hline Cebidae & Sapajus flavius & CR & $\mathrm{D}$ & Rural Proximity \\
\hline Cebidae & Sapajus flavius & $\mathrm{CR}$ & $\mathrm{D}$ & Pet \\
\hline Cebidae & Sapajus flavius & $\mathrm{CR}$ & $\mathrm{D}$ & Hunting \\
\hline Cebidae & Cebus albifrons & $\mathrm{LC}$ & $\mathrm{D}$ & Rural Proximity \\
\hline Pitheciidae & Chiropotes satanas & $\mathrm{CR}$ & $\mathrm{D}$ & Hunting \\
\hline Pitheciidae & Chiropotes satanas & $\mathrm{CR}$ & $\mathrm{D}$ & Rural Proximity \\
\hline Pitheciidae & Chiropotes satanas & CR & $\mathrm{D}$ & Hunting \\
\hline Pitheciidae & Chiropotes satanas & $\mathrm{CR}$ & $\mathrm{D}$ & Rural Proximity \\
\hline Pitheciidae & Chiropotes satanas & $\mathrm{CR}$ & $\mathrm{D}$ & Hunting \\
\hline Pitheciidae & Chiropotes satanas & $\mathrm{CR}$ & $\mathrm{D}$ & $\begin{array}{l}\text { Rural Proximity } \\
\text { Mystic/Folklore/ }\end{array}$ \\
\hline Pitheciidae & Chiropotes satanas & CR & $\mathrm{D}$ & $\begin{array}{l}\text { Magic/Religion/ } \\
\text { Ritual }\end{array}$ \\
\hline Pitheciidae & Chiropotes satanas & CR & $\mathrm{D}$ & $\begin{array}{l}\text { Rural Proximity } \\
\text { Mystic/Folklore/ }\end{array}$ \\
\hline Pitheciidae & Chiropotes chiropotes & $\mathrm{LC}$ & S & $\begin{array}{l}\text { Magic/Religion/ } \\
\text { Ritual }\end{array}$ \\
\hline Pitheciidae & Chiropotes chiropotes & $\mathrm{LC}$ & $\mathrm{S}$ & Rural Proximity \\
\hline
\end{tabular}

\begin{tabular}{|c|c|c|c|}
\hline RO & A & Ye'kwana & Cornier \\
\hline $\mathrm{AM}$ & A & Matses & Cornier \\
\hline $\mathrm{AM}$ & A & Matses & Cornier \\
\hline MT & A & Kalapalo & Cornier \\
\hline MT & $\mathrm{A}$ & Kalapalo & Cornier \\
\hline MT & A & Mechinaku & Cornier \\
\hline MT & $\mathrm{A}$ & Mechinaku & Cornier \\
\hline RO & A & Warí & Cornier \\
\hline RO & $\mathrm{A}$ & Warí & Cornier \\
\hline PA & $\mathrm{C}$ & Maringá & Rapchan \\
\hline PA & $\mathrm{C}$ & Maringá & Rapchan \\
\hline $\mathrm{AM}$ & A & Vale do Juruá & Nunes et al \\
\hline $\mathrm{BA}$ & PA & $\begin{array}{l}\text { Rio São Fran- } \\
\text { cisco }\end{array}$ & Batista \\
\hline $\mathrm{BA}$ & PA & $\begin{array}{l}\text { Rio São Fran- } \\
\text { cisco }\end{array}$ & Batista \\
\hline $\mathrm{BA}$ & PA & $\begin{array}{l}\text { Rio São Fran- } \\
\text { cisco }\end{array}$ & Batista \\
\hline BA & $\mathrm{PA}$ & $\begin{array}{l}\text { Rio São Fran- } \\
\text { cisco }\end{array}$ & Batista \\
\hline $\mathrm{AM}$ & $\mathrm{A}$ & Vale do Juruá & Nunes et al \\
\hline MA & A & Guajá & Cornier \\
\hline MA & A & Guajá & Cornier \\
\hline $\mathrm{CB}$ & A & $\begin{array}{l}\text { Waimiri } \\
\text { Atroari }\end{array}$ & Cornier \\
\hline $\mathrm{CB}$ & $\mathrm{A}$ & $\begin{array}{l}\text { Waimiri } \\
\text { Atroari }\end{array}$ & Cornier \\
\hline $\mathrm{RO}$ & A & Wapishana & Cornier \\
\hline RO & $\mathrm{A}$ & Wapishana & Cornier \\
\hline MA & $\mathrm{A}$ & Guajá & Cornier \\
\hline MA & $\mathrm{A}$ & Guajá & Cornier \\
\hline $\mathrm{AM}$ & $\mathrm{A}$ & Yanomami & Cornier \\
\hline $\mathrm{AM}$ & A & Yanomami & Cornier \\
\hline
\end{tabular}

\begin{tabular}{|c|c|}
\hline 2006 & Rural \\
\hline 2006 & Rural \\
\hline 2006 & Rural \\
\hline 2006 & Rural \\
\hline 2006 & Rural \\
\hline 2006 & Rural \\
\hline 2006 & Rural \\
\hline 2006 & Rural \\
\hline 2006 & Rural \\
\hline 2016 & Urban \\
\hline 2016 & Urban \\
\hline 2017 & Rural \\
\hline 2017 & Rural \\
\hline 2017 & Rural \\
\hline 2017 & Rural \\
\hline 2017 & Rural \\
\hline 2017 & Rural \\
\hline 2006 & Rural \\
\hline 2006 & Rural \\
\hline 2006 & Rural \\
\hline 2006 & Rural \\
\hline 2006 & Rural \\
\hline 2006 & Rural \\
\hline 2006 & Rural \\
\hline 2006 & Rural \\
\hline 2006 & Rural \\
\hline
\end{tabular}




\begin{tabular}{|c|c|c|c|c|}
\hline Pitheciidae & Chiropotes chiropotes & $\mathrm{LC}$ & $\mathrm{S}$ & $\begin{array}{l}\text { Mystic/Folklore/ } \\
\text { Magic/Religion/ } \\
\text { Ritual }\end{array}$ \\
\hline Pitheciidae & Chiropotes chiropotes & $\mathrm{LC}$ & $\mathrm{S}$ & Rural Proximity \\
\hline Pitheciidae & Chiropotes satanas & $\mathrm{CR}$ & $\mathrm{D}$ & Pet \\
\hline Pitheciidae & Chiropotes satanas & $\mathrm{CR}$ & $\mathrm{D}$ & Rural Proximity \\
\hline Pitheciidae & Chiropotes satanas & $\mathrm{CR}$ & $\mathrm{D}$ & $\begin{array}{l}\text { Hunting } \\
\text { Mystic/Folklore/ }\end{array}$ \\
\hline Pitheciidae & Chiropotes satanas & $\mathrm{CR}$ & $\mathrm{D}$ & $\begin{array}{l}\text { Magic/Religion/ } \\
\text { Ritual } \\
\text { Mystic/Folklore/ }\end{array}$ \\
\hline Pitheciidae & Chiropotes chiropotes & $\mathrm{LC}$ & $\mathrm{S}$ & $\begin{array}{l}\text { Mystic/Folklore/ } \\
\text { Magic/Religion/ } \\
\text { Ritual }\end{array}$ \\
\hline Pitheciidae & Chiropotes chiropotes & $\mathrm{LC}$ & $\mathrm{S}$ & Medicinal \\
\hline Pitheciidae & Chiropotes satanas & $\mathrm{CR}$ & $\mathrm{D}$ & Medicinal \\
\hline Atelidae & Lagothrix lagothricha & VU & $\mathrm{D}$ & Hunting \\
\hline Atelidae & Lagothrix lagothricha & VU & $\mathrm{D}$ & Rural Proximity \\
\hline Atelidae & Lagothrix sp. & & & Hunting \\
\hline Atelidae & Lagothrix sp. & & & Rural Proximity \\
\hline Atelidae & Lagothrix lagothricha & VU & $\mathrm{D}$ & Hunting \\
\hline Atelidae & Lagothrix lagothricha & VU & $\mathrm{D}$ & Rural Proximity \\
\hline Atelidae & Lagothrix lagothricha & VU & $\mathrm{D}$ & Hunting \\
\hline Atelidae & Lagothrix lagothricha & VU & $\mathrm{D}$ & Rural Proximity \\
\hline Atelidae & Lagothrix lagothricha & VU & $\mathrm{D}$ & Medicinal \\
\hline Atelidae & Lagothrix lagothricha & VU & $\mathrm{D}$ & Hunting \\
\hline Atelidae & Lagothrix lagothricha & VU & $\mathrm{D}$ & Rural Proximity \\
\hline Atelidae & Lagothrix lagothricha & VU & $\mathrm{D}$ & Pet \\
\hline Atelidae & Lagothrix lagothricha & VU & $\mathrm{D}$ & Medicinal \\
\hline Cebidae & Saguinus illigeri & $\mathrm{LC}$ & $\mathrm{D}$ & Urban Proximity \\
\hline Pitheciidae & Pithecia hirsuta & DD & $\mathrm{D}$ & Hunting \\
\hline Pitheciidae & Pithecia hirsuta & $\mathrm{DD}$ & $\mathrm{D}$ & Rural Proximity \\
\hline Pitheciidae & Pithecia pithecia & $\mathrm{LC}$ & $\mathrm{D}$ & Hunting \\
\hline Pitheciidae & Pithecia pithecia & $\mathrm{LC}$ & $\mathrm{D}$ & Rural Proximity \\
\hline Pitheciidae & Pithecia sp. & & & Urban Proximity \\
\hline Pitheciidae & Pithecia vanzolinii & $\mathrm{DD}$ & $\mathrm{D}$ & Hunting \\
\hline Pitheciidae & Pithecia vanzolinii & DD & $\mathrm{D}$ & Rural Proximity \\
\hline Pitheciidae & Plecturocebus cupreus & $\mathrm{LC}$ & $\mathrm{U}$ & Urban Proximity \\
\hline Cebidae & Saguinus midas & $\mathrm{LC}$ & $\mathrm{S}$ & Hunting \\
\hline Cebidae & Saguinus midas & $\mathrm{LC}$ & $\mathrm{S}$ & Rural Proximity \\
\hline Cebidae & Saguinus mystax & & & Hunting \\
\hline Cebidae & Saguinus mystax & & & Rural Proximity \\
\hline
\end{tabular}

$\begin{array}{lll}\text { RO } & \text { A } & \text { Yanomami } \\ & & \\ \text { RO } & \text { A } & \text { Yanomami } \\ \text { MA } & \text { A } & \text { Guajá } \\ \text { MA } & \text { A } & \text { Guajá } \\ \text { MA } & \text { A } & \text { Guajá } \\ & & \\ \text { U } & \text { U } & \text { U } \\ & & \\ & & \\ \text { U } & \text { U } & \text { U } \\ & & \\ \text { U } & \text { U } & \text { U } \\ \text { U } & \text { U } & \text { U } \\ \text { AM } & \text { A } & \text { Maku } \\ \text { AM } & \text { A } & \text { Maku } \\ \text { AM } & \text { A } & \text { Makuna } \\ \text { AM } & \text { A } & \text { Makuna } \\ \text { AM } & \text { A } & \text { Matis } \\ \text { AM } & \text { A } & \text { Matis } \\ \text { AM } & \text { A } & \text { Matses } \\ \text { AM } & \text { A } & \text { Matses } \\ \text { U } & \text { U } & \text { U } \\ \text { AM } & \text { U } & \text { U } \\ \text { AM } & \text { U } & \text { U } \\ \text { AM } & \text { U } & \text { U } \\ \text { U } & \text { U } & \text { U } \\ \text { AC } & \text { A } & \text { Cruzeiro do } \\ & & \text { Sul } \\ \text { AM } & \text { A } & \text { Matses } \\ \text { AM } & \text { A } & \text { Matses } \\ \text { RO } & \text { A } & \text { Wapishana } \\ \text { RO } & \text { A } & \text { Wapishana } \\ \text { AC } & \text { A } & \text { Cruzeiro do } \\ & & \text { Sul } \\ \text { AM } & \text { A } & \text { Vale do Juruá } \\ \text { AM } & \text { A } & \text { Vale do Juruá } \\ \text { AC } & \text { A } & \text { Cruzeiro do } \\ & & \text { Sul } \\ \text { MA } & \text { A } & \text { Guajá } \\ \text { MA } & \text { A } & \text { Guajá } \\ \text { AM } & \text { A } & \text { Matis } \\ \text { AM } & \text { A } & \text { Matis } \\ & & \end{array}$

\begin{tabular}{|c|c|c|}
\hline Cornier & 2006 & Rural \\
\hline Cornier & 2006 & Rural \\
\hline Cornier & 2003 & Rural \\
\hline Cornier & 2003 & Rural \\
\hline Cornier & 2003 & Rural \\
\hline Alves et al & 2016 & $\mathrm{U}$ \\
\hline Alves et al & 2012 & $\mathrm{U}$ \\
\hline Alves \& Barboza & 2017 & $\mathrm{U}$ \\
\hline Alves \& Barboza & 2017 & $\mathrm{U}$ \\
\hline Cornier & 2006 & Rural \\
\hline Cornier & 2006 & Rural \\
\hline Cornier & 2006 & Rural \\
\hline Cornier & 2006 & Rural \\
\hline Cornier & 2006 & Rural \\
\hline Cornier & 2006 & Rural \\
\hline Cornier & 2006 & Rural \\
\hline Cornier & 2006 & Rural \\
\hline Alves et al & 2012 & $\mathrm{U}$ \\
\hline Peres & 1991 & Rural \\
\hline Peres & 1991 & Rural \\
\hline Peres & 1991 & Rural \\
\hline Alves \& Barboza & 2017 & $\mathrm{U}$ \\
\hline Araújo \& Liesenfeld & 2017 & Urban \\
\hline Cornier & 2006 & Rural \\
\hline Cornier & 2006 & Rural \\
\hline Cornier & 2006 & Rural \\
\hline Cornier & 2006 & Rural \\
\hline Araújo \& Liesenfeld & 2017 & Urban \\
\hline Nunes et al & 2017 & Rural \\
\hline Nunes et al & 2017 & Rural \\
\hline Araújo \& Liesenfeld & 2017 & Urban \\
\hline Cornier & 2006 & Rural \\
\hline Cornier & 2006 & Rural \\
\hline Cornier & 2006 & Rural \\
\hline Cornier & 2006 & Rural \\
\hline
\end{tabular}




\begin{tabular}{|c|c|c|c|c|c|c|c|c|}
\hline Cebidae & Saguinus midas & $\mathrm{LC}$ & $\mathrm{S}$ & Hunting & $\mathrm{RO}$ & $\mathrm{A}$ & Wapishana & Cornier \\
\hline Cebidae & Saguinus midas & $\mathrm{LC}$ & $\mathrm{S}$ & Rural Proximity & $\mathrm{RO}$ & $\mathrm{A}$ & Wapishana & Cornier \\
\hline Cebidae & Saguinus midas & $\mathrm{LC}$ & $\mathrm{S}$ & Taboo/Eating avoidance & MA & $\mathrm{A}$ & Guajá & Cornier \\
\hline Cebidae & Saguinus midas & $\mathrm{LC}$ & $\mathrm{S}$ & Rural Proximity & MA & $\mathrm{A}$ & Guajá & Cornier \\
\hline Cebidae & Saguinus mystax & & & Taboo/Eating avoidance & $\mathrm{AM}$ & $\mathrm{A}$ & Matis & Cornier \\
\hline Cebidae & Saguinus mystax & & & $\begin{array}{l}\text { Rural Proximity } \\
\text { Mystic/Folklore/ }\end{array}$ & $\mathrm{AM}$ & $\mathrm{A}$ & Matis & Cornier \\
\hline Cebidae & Saguinus midas & $\mathrm{LC}$ & $\mathrm{S}$ & $\begin{array}{l}\text { Magic/Religion/ } \\
\text { Ritual }\end{array}$ & MA & $\mathrm{A}$ & Guajá & Cornier \\
\hline Cebidae & Saguinus midas & $\mathrm{LC}$ & $\mathrm{S}$ & Rural Proximity & MA & $\mathrm{A}$ & Guajá & Cornier \\
\hline Cebidae & Saguinus midas & $\mathrm{LC}$ & $\mathrm{S}$ & Pet & MA & $\mathrm{A}$ & Guajá & Cornier \\
\hline Cebidae & Saguinus midas & $\mathrm{LC}$ & $\mathrm{S}$ & Rural Proximity & MA & $\mathrm{A}$ & Guajá & Cornier \\
\hline Cebidae & Saguinus midas & $\mathrm{LC}$ & $\mathrm{S}$ & $\begin{array}{l}\text { Hunting } \\
\text { Mystic/Folklore/ }\end{array}$ & MA & $\mathrm{A}$ & Guajá & Cornier \\
\hline Cebidae & Saguinus midas & $\mathrm{LC}$ & $\mathrm{S}$ & $\begin{array}{l}\text { Magic/Religion/ } \\
\text { Ritual }\end{array}$ & $\mathrm{U}$ & $\mathrm{U}$ & $\mathrm{U}$ & Alves et al \\
\hline Cebidae & Saguinus bicolor & $\mathrm{CR}$ & $\mathrm{D}$ & Urban Proximity & $\mathrm{AM}$ & $\mathrm{U}$ & Manaus & Santos et al \\
\hline Cebidae & Saguinus bicolor & $\mathrm{CR}$ & $\mathrm{D}$ & Food offering & $\mathrm{AM}$ & $\mathrm{U}$ & Manaus & Santos et al \\
\hline Cebidae & Saguinus bicolor & $\mathrm{CR}$ & $\mathrm{D}$ & Home Invasion & $\mathrm{AM}$ & $\mathrm{U}$ & Manaus & Santos et al \\
\hline Cebidae & Saguinus midas & $\mathrm{LC}$ & $\mathrm{S}$ & Medicinal & $\mathrm{U}$ & $\mathrm{U}$ & $\mathrm{U}$ & Alves \& Barboza \\
\hline Cebidae & Saguinus bicolor & $\mathrm{CR}$ & $\mathrm{D}$ & Urban Proximity & $\mathrm{AM}$ & $\mathrm{U}$ & Manaus & Gordo et al \\
\hline Cebidae & Saimiri sciureus & $\mathrm{LC}$ & $\mathrm{D}$ & Hunting & MA & $\mathrm{A}$ & Guajá & Cornier \\
\hline Cebidae & Saimiri sciureus & $\mathrm{LC}$ & $\mathrm{D}$ & Rural Proximity & MA & $\mathrm{A}$ & Guajá & Cornier \\
\hline Cebidae & Saimiri sciureus & $\mathrm{LC}$ & $\mathrm{D}$ & Hunting & $\mathrm{AM}$ & $\mathrm{A}$ & Matis & Cornier \\
\hline Cebidae & Saimiri sciureus & $\mathrm{LC}$ & $\mathrm{D}$ & Rural Proximity & $\mathrm{AM}$ & $\mathrm{A}$ & Matis & Cornier \\
\hline Cebidae & Saimiri sciureus & $\mathrm{LC}$ & $\mathrm{D}$ & Hunting & $\mathrm{RO}$ & $\mathrm{A}$ & Wapishana & Cornier \\
\hline Cebidae & Saimiri sciureus & $\mathrm{LC}$ & $\mathrm{D}$ & Rural Proximity & RO & $\mathrm{A}$ & Wapishana & Cornier \\
\hline Cebidae & Saimiri sciureus & $\mathrm{LC}$ & $\mathrm{D}$ & Taboo/Eating avoidance & $\mathrm{AM}$ & $\mathrm{A}$ & Matis & Cornier \\
\hline Cebidae & Saimiri sciureus & $\mathrm{LC}$ & $\mathrm{D}$ & $\begin{array}{l}\text { Rural Proximity } \\
\text { Mystic/Folklore/ }\end{array}$ & $\mathrm{AM}$ & $\mathrm{A}$ & Matis & Cornier \\
\hline Cebidae & Saimiri sciureus & $\mathrm{LC}$ & $\mathrm{D}$ & $\begin{array}{l}\text { Magic/Religion/ } \\
\text { Ritual }\end{array}$ & MA & $\mathrm{A}$ & Guajá & Cornier \\
\hline Cebidae & Saimiri sciureus & $\mathrm{LC}$ & $\mathrm{D}$ & Pet & MA & $\mathrm{A}$ & Guajá & Cornier \\
\hline Cebidae & Saimiri sciureus & $\mathrm{LC}$ & $\mathrm{D}$ & Hunting & MA & $\mathrm{A}$ & Guajá & Cornier \\
\hline Cebidae & Saimiri sciureus & $\mathrm{LC}$ & $\mathrm{D}$ & $\begin{array}{l}\text { Rural Proximity } \\
\text { Mystic/Folklore/ }\end{array}$ & MA & $\mathrm{A}$ & Guajá & Cornier \\
\hline Cebidae & Saimiri sciureus & $\mathrm{LC}$ & $\mathrm{D}$ & $\begin{array}{l}\text { Magic/Religion/ } \\
\text { Ritual }\end{array}$ & $\mathrm{U}$ & $\mathrm{U}$ & $\mathrm{U}$ & Alves et al \\
\hline Cebidae & Saimiri sciureus & $\mathrm{LC}$ & $\mathrm{D}$ & Urban Proximity & $\mathrm{PA}$ & $\mathrm{A}$ & $\begin{array}{l}\text { Jardim } \\
\text { Botânico } \\
\text { Bosque Ro- } \\
\text { drigues Alves }\end{array}$ & Silveira \\
\hline
\end{tabular}

\begin{tabular}{|c|c|}
\hline 2006 & Rural \\
\hline 2006 & Rural \\
\hline 2006 & Rural \\
\hline 2006 & Rural \\
\hline 2006 & Rural \\
\hline 2006 & Rural \\
\hline 2006 & Rural \\
\hline 2006 & Rural \\
\hline 2003 & Rural \\
\hline 2003 & Rural \\
\hline 2003 & Rural \\
\hline 2016 & $\mathrm{U}$ \\
\hline 2017 & Urban \\
\hline 2017 & Urban \\
\hline 2017 & Urban \\
\hline 2017 & $\mathrm{U}$ \\
\hline 2013 & Urban \\
\hline 2006 & Rural \\
\hline 2006 & Rural \\
\hline 2006 & Rural \\
\hline 2006 & Rural \\
\hline 2006 & Rural \\
\hline 2006 & Rural \\
\hline 2006 & Rural \\
\hline 2006 & Rural \\
\hline 2006 & Rural \\
\hline 2003 & Rural \\
\hline 2003 & Rural \\
\hline 2003 & Rural \\
\hline 2016 & $\mathrm{U}$ \\
\hline 2017 & Urban \\
\hline
\end{tabular}




\begin{tabular}{|c|c|c|c|c|}
\hline Cebidae & Saimiri sciureus & $\mathrm{LC}$ & $\mathrm{D}$ & Garbage foraging \\
\hline Cebidae & Saimiri sciureus & $\mathrm{LC}$ & $\mathrm{D}$ & Food offering \\
\hline Cebidae & Saimiri vanzolinii & VU & $\mathrm{U}$ & Tourism \\
\hline Cebidae & Saimiri vanzolinii & $\mathrm{VU}$ & $\mathrm{U}$ & Rural Proximity \\
\hline Cebidae & Saimiri sciureus & $\mathrm{LC}$ & $\mathrm{D}$ & Tourism \\
\hline Cebidae & Saimiri boliviensis & $\mathrm{LC}$ & $\mathrm{D}$ & Urban Proximity \\
\hline Cebidae & Saimiri boliviensis & $\mathrm{LC}$ & $\mathrm{D}$ & Hunting \\
\hline Cebidae & Saimiri sciureus & $\mathrm{LC}$ & $\mathrm{D}$ & Medicinal \\
\hline Cebidae & Sapajus flavius & EN & $\mathrm{D}$ & Rural Proximity \\
\hline Cebidae & Sapajus libidinosus & NT & $\mathrm{D}$ & Crop raiding \\
\hline Cebidae & Sapajus libidinosus & NT & $\mathrm{D}$ & Poisoning \\
\hline Cebidae & Sapajus libidinosus & NT & $\mathrm{D}$ & Rural Proximity \\
\hline Cebidae & Sapajus libidinosus & NT & $\mathrm{D}$ & Urban Proximity \\
\hline Cebidae & Sapajus libidinosus & NT & $\mathrm{D}$ & Food offering \\
\hline Cebidae & Sapajus libidinosus & NT & $\mathrm{D}$ & Crop raiding \\
\hline Cebidae & Sapajus libidinosus & NT & $\mathrm{D}$ & Rural Proximity \\
\hline Cebidae & Sapajus libidinosus & NT & $\mathrm{D}$ & Urban Proximity \\
\hline Cebidae & Sapajus libidinosus & NT & $\mathrm{D}$ & Food offering \\
\hline Cebidae & Sapajus libidinosus & NT & $\mathrm{D}$ & Garbage foraging \\
\hline Cebidae & Sapajus libidinosus & NT & $\mathrm{D}$ & Urban Proximity \\
\hline Cebidae & Sapajus libidinosus & NT & $\mathrm{D}$ & Food offering \\
\hline Cebidae & Sapajus libidinosus & NT & $\mathrm{D}$ & Garbage foraging \\
\hline Cebidae & Sapajus apella & $\mathrm{LC}$ & $\mathrm{D}$ & Tourism \\
\hline
\end{tabular}

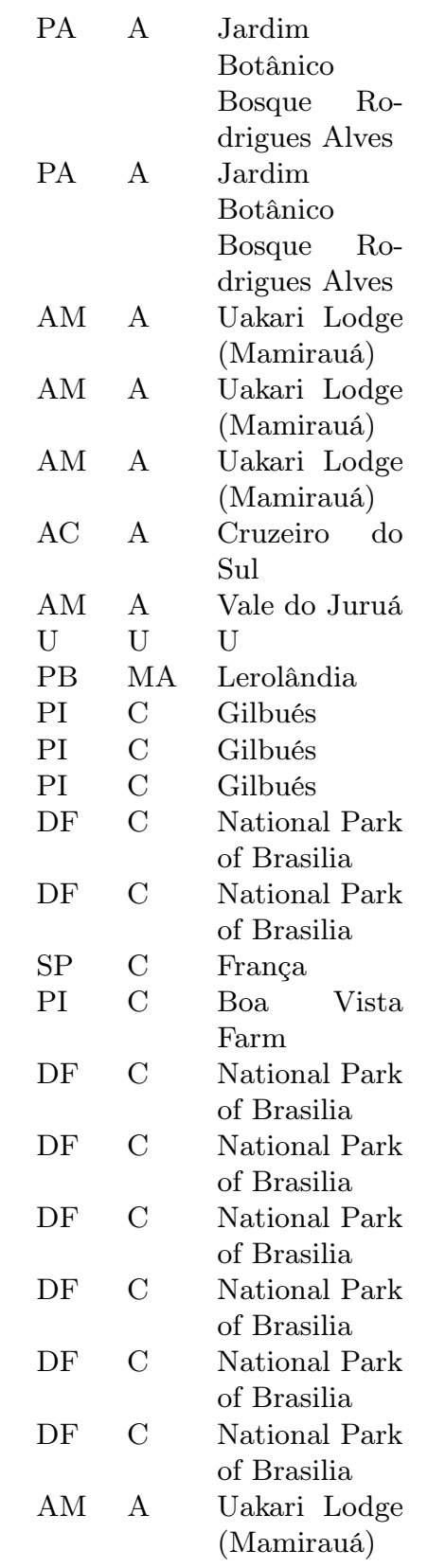

Silveira

2017

Urban

Silveira

2017

Urban

Paim et al

2012

Paim et al

Rural

Paim et al

Araújo \& Liesenfeld

Nunes et al

Alves \& Barboza

Torres

Spagnoletti

Spagnoletti

Spagnoletti

Sabbatini

Sabbatini

de Freitas

Rapchan \& Neves

Saito et al

Saito et al

Saito et al

Sabbatini

Sabbatini

Sabbatini

Paim et al 


\begin{tabular}{|c|c|c|c|c|c|c|c|c|c|c|}
\hline Cebidae & Sapajus apella & $\mathrm{LC}$ & $\mathrm{D}$ & Rural Proximity & $\mathrm{AM}$ & $\mathrm{A}$ & $\begin{array}{l}\text { Uakari Lodge } \\
\text { (Mamirauá) }\end{array}$ & Paim et al & 2012 & Rural \\
\hline Cebidae & Sapajus apella & $\mathrm{LC}$ & $\mathrm{D}$ & Hunting & $\mathrm{AM}$ & $\mathrm{A}$ & Vale do Juruá & Nunes et al & 2017 & Rural \\
\hline Cebidae & Sapajus apella & $\mathrm{LC}$ & $\mathrm{D}$ & Medicinal & $\mathrm{AM}$ & $\mathrm{A}$ & Vale do Juruá & Nunes et al & 2017 & Rural \\
\hline Cebidae & Sapajus apella & $\mathrm{LC}$ & $\mathrm{D}$ & Rural Proximity & $\mathrm{AM}$ & $\mathrm{A}$ & Vale do Juruá & Nunes et al & 2017 & Rural \\
\hline Cebidae & Sapajus sp. & & & Urban Proximity & $\mathrm{PR}$ & MA & Foz do Iguaçu & Suzin & 2014 & Urban \\
\hline Cebidae & Sapajus sp. & & & Food offering & $\mathrm{PR}$ & MA & Foz do Iguaçu & Suzin & 2014 & Urban \\
\hline Cebidae & Sapajus sp. & & & Rural Proximity & $\mathrm{RS}$ & MA & $\begin{array}{l}\text { Hydroeletric } \\
\text { power plant }\end{array}$ & Rocha & 2015 & Rural \\
\hline Cebidae & Sapajus sp. & & & Crop raiding & $\mathrm{RS}$ & MA & $\begin{array}{l}\text { Hydroeletric } \\
\text { power plant }\end{array}$ & Rocha & 2015 & Rural \\
\hline Cebidae & Sapajus sp. & & & Home Invasion & $\mathrm{RS}$ & MA & $\begin{array}{l}\text { Hydroeletric } \\
\text { power plant }\end{array}$ & Rocha & 2015 & Rural \\
\hline Cebidae & Sapajus sp. & & & Hunting & $\mathrm{RS}$ & MA & $\begin{array}{l}\text { Hydroeletric } \\
\text { power plant }\end{array}$ & Rocha & 2015 & Rural \\
\hline Cebidae & Sapajus sp. & & & Poaching & $\mathrm{RS}$ & MA & $\begin{array}{l}\text { Hydroeletric } \\
\text { power plant }\end{array}$ & Rocha & 2015 & Rural \\
\hline Cebidae & Sapajus sp. & & & Pet & $\mathrm{RS}$ & MA & $\begin{array}{l}\text { Hydroeletric } \\
\text { power plant }\end{array}$ & Rocha & 2015 & Rural \\
\hline Cebidae & Sapajus sp. & & & Hunting & MA & $\mathrm{A}$ & Guajá & Cornier & 2003 & Rural \\
\hline $\mathrm{U}$ & $U s p$ & & & Taboo/Eating avoidance & MT & $\mathrm{A}$ & Mekronoti & Cornier & 2006 & Rural \\
\hline
\end{tabular}


Add File 5. All chi-square results.

\begin{tabular}{|c|c|c|c|c|c|}
\hline & GENUS & STATUS & STATES & BIOMES & Human Settlement \\
\hline Hunting & & & Unespecified $(-4,1)$ & $\begin{array}{l}\text { Amazon }(4,2) \\
\text { Cerrado }(-3,2)\end{array}$ & $\begin{array}{l}\text { Urban }(-4,1) \\
\text { Rural }(4,1)\end{array}$ \\
\hline Medicinal & & & Unespecified(10,5) & & \\
\hline Mystic & & & MA $(6,0)$ & & \\
\hline Pet & & & MA $(4,3)$ & & \\
\hline Food Offering & Callithrix $(5,0)$ & Near-Threatened $(4,2)$ & $\begin{array}{l}\mathrm{DF}(6,5) \\
\mathrm{MG}(4,0) \\
\operatorname{PE}(4,0) \\
\operatorname{PR}(4,0)\end{array}$ & $\begin{array}{l}\text { Amazon }(-6,1) \\
\text { Cerrado }(5,3) \\
\text { Atlantic Forest }(3,0)\end{array}$ & $\begin{array}{l}\text { Urban }(8,5) \\
\text { Rural }(-8,5)\end{array}$ \\
\hline Crop-Raiding & Sapajus $(3,2)$ & Near-Threatened $(5,1)$ & $\begin{array}{l}\mathrm{PI}(4,0) \\
\mathrm{RS}(4,5) \\
\mathrm{SP}(8,2)\end{array}$ & $\begin{array}{l}\text { Amazon }(-5,2) \\
\text { Cerrado }(4,2)\end{array}$ & $\begin{array}{l}\text { Urban }(3,2) \\
\text { Rural }(-3,2)\end{array}$ \\
\hline Garbage Foraging & & Near-Threatened $(3,8)$ & $\mathrm{DF}(6,0)$ & Cerrado $(3,7)$ & $\begin{array}{l}\text { Urban }(4,5) \\
\text { Rural }(-4,5)\end{array}$ \\
\hline Poaching & & & $\mathrm{RS}(5,3)$ & Atlantic Forest $(3,5)$ & $\begin{array}{l}\text { Urban }(4,0) \\
\text { Rural }(-4,0)\end{array}$ \\
\hline $\begin{array}{l}\text { Poisoning } \\
\text { Taboo }\end{array}$ & & Near-Threatened $(3,4)$ & PI $(9,3)$ & Cerrado $(3,3)$ & Rural $(4,0)$ \\
\hline Tourism & & & $\mathrm{AM}(3,6)$ & & \\
\hline Home Invasion & & & $\begin{array}{l}\text { BA }(3,2) \\
\text { PA }(4,1)\end{array}$ & $\begin{array}{l}\text { Amazon }(-4,0) \\
\text { Atlantic Forest }(3,9)\end{array}$ & \\
\hline $\begin{array}{l}\text { GENUS } \\
\text { Asymptotic }\end{array}$ & & & & & Callithrix x Rural $(-3,8)$ \\
\hline $\begin{array}{l}\text { Significance } \\
\text { (2-sided) } \\
\text { Chi-squared }\end{array}$ & 0,202 & 0 & 0 & 0 & 0 \\
\hline
\end{tabular}


Add File 6. PCA Genus x Interactions.

\begin{tabular}{llllll}
\hline \hline & \multicolumn{2}{c}{ PCA Genus x Interactions COS2 } & & \\
Interactions/Dimensions & Dim1 & Dim2 & Dim3 & Dim4 & Dim5 \\
HUNTING & 0.8379464145 & 0.11626991 & 0.04423623 & $2.978163 \mathrm{e}-04$ & 0.0010705450 \\
PET & 0.2343946578 & 0.07409710 & 0.43276062 & $1.275476 \mathrm{e}-01$ & 0.0832449577 \\
MEDICINAL & 0.7801944731 & 0.02036162 & 0.04918060 & $7.467078 \mathrm{e}-02$ & 0.0660781748 \\
MYSTIC & 0.7026972117 & 0.24213607 & 0.01453994 & $3.906108 \mathrm{e}-02$ & 0.0001688667 \\
FOOD OFFERING & 0.0007402746 & 0.72509012 & 0.24766817 & $1.414109 \mathrm{e}-02$ & 0.0080485098 \\
CROP RAIDING & 0.3508843770 & 0.57217013 & 0.05246892 & $5.207204 \mathrm{e}-03$ & 0.0079753594 \\
GARBAGE FORAGING & 0.1101274614 & 0.71248408 & 0.01351019 & $5.395801 \mathrm{e}-05$ & 0.0012286502 \\
POACHING & 0.1716206079 & 0.76128962 & 0.01918365 & $2.146479 \mathrm{e}-02$ & 0.0083714442 \\
POISONING & 0.1716206079 & 0.76128962 & 0.01918365 & $2.146479 \mathrm{e}-02$ & 0.0083714442 \\
TABOO & 0.4144271277 & 0.30557338 & 0.05385769 & $9.948884 \mathrm{e}-02$ & 0.1174204726 \\
TOURISM & 0.1636039174 & 0.05783252 & 0.04069750 & $1.015373 \mathrm{e}-01$ & 0.0381095253 \\
HOME INVASION & 0.0154404117 & 0.20822742 & 0.10605695 & $1.432766 \mathrm{e}-01$ & 0.2090257035 \\
\hline \hline
\end{tabular}

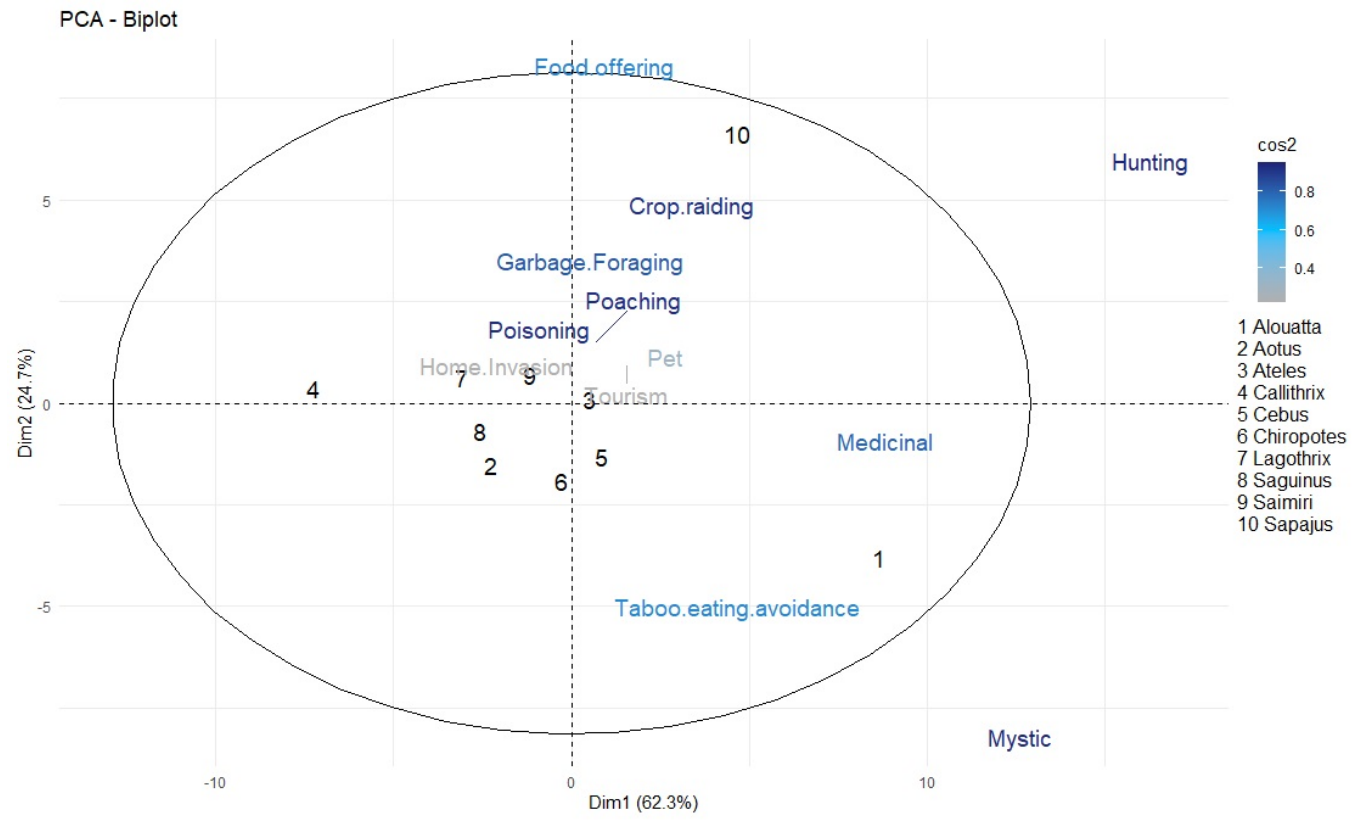

Add File 7. PCA Genus x Interactions Biplot Graph Output R Statistics. 